\title{
Recent advances in heighten sulfur resistance of SCR catalysts: A review
}

\author{
Ling Zhao ${ }^{\dagger}$, Yu Zhang, Mengdi Kang \\ School of Ecology and Environment, Inner Mongolia University, China
}

\begin{abstract}
$\mathrm{NO}_{\mathrm{x}}$ removal by selective catalytic reduction (SCR) technology is a research hotspot in the field of environmental catalysis, and this method is dominated by catalysts. However, denitrification catalyst is easy to be polluted by the presence of $\mathrm{SO}_{2}$, which seriously restricts its practical industrial application. This review focuses on the latest domestic and foreign research results and advancement in improving sulfur resistance of deNO ${ }_{x}$ catalysts, reveals the sulfur poisoning mechanism and regeneration process, as well as introduces the positive role of quantum chemistry in the field of sulfur resistance. In view of the questions set forth in this review, the future development direction of deNO $\mathrm{O}_{\mathrm{x}}$ catalysts is prospected, which provides valuable scientific guidance for the design and development of efficient and practical sulfur resistant deNO $\mathrm{x}_{\mathrm{x}}$ catalysts.
\end{abstract}

Keywords: deNO ${ }_{x}$ catalyst, DFT, Regeneration, Selective catalytic reduction, Sulfur poisoning

\section{Introduction}

China's rapid economic growth has caused severe air pollution, and people are increasingly concerned about its negative impact on health, environment and sustainable economic development. Similar to most industrialized countries, China is currently changing from $\mathrm{SO}_{2}$-based air pollution to $\mathrm{NO}_{\mathrm{x}}$ and $\mathrm{O}_{3}$-based air pollution [1]. It is well known that nitric oxide (NO) and nitrogen dioxide $\left(\mathrm{NO}_{2}\right)$ are the main types of nitrogen oxides $\left(\mathrm{NO}_{\mathrm{x}}\right)$ in China. The combustion of fossil fuels and vehicle exhaust emissions are the main sources of pollution [2]. According to official statistics released by the Chinese government, China's $\mathrm{NO}_{\mathrm{x}}$ emissions are expected to reach 42.96 million tons in 2030 without reasonable measures to control $\mathrm{NO}_{\mathrm{x}}$ emissions. The Outline of the National 13th Five-Year Plan has clearly stated that $\mathrm{NO}_{\mathrm{x}}$ emission will be reduced by $15 \%$ within 5 years. In the 2019 government work report, Premier Li Keqiang clearly pointed out that $\mathrm{NO}_{\mathrm{x}}$ emissions should be reduced by $3 \%$ [3]. In the face of increasingly stringent pollutant emission standards, the elimination of $\mathrm{NO}_{\mathrm{x}}$ has become a hot spot in the environmental protection field.

Post-combustion flue gas purification technologies mainly include solid adsorption, liquid absorption, selective catalytic reduction, catalytic decomposition, plasma catalysis, and microbial meth- od [4]. Among them, selective catalytic reduction (SCR) is considered as the mainstream method for $\mathrm{NO}_{\mathrm{x}}$ removal due to its high deNO$_{\mathrm{x}}$ efficiency, excellent selectivity and practicability. The catalyst is the core part of the technology, and its performance will directly affect the deNO $\mathrm{x}_{\mathrm{x}}$ effect of SCR system. In addition, the catalyst cost accounts for a large proportion of the total cost of the SCR system. At present, due to the tremendous progress in material preparation science and technology, academic researchers and engineers have developed a number of SCR catalysts with high $\mathrm{NO}_{\mathrm{x}}$ removal efficiency in $\mathrm{SO}_{2}$-free flue gas. However, the $\mathrm{SO}_{2}$ contained in the actual flue gas will inevitably lead to catalyst poisoning and deactivation, reducing catalytic efficiency and service life, which has become a major obstacle restricting the practical industrial application of the catalyst. Therefore, it is urgent to develop catalytic materials with excellent activity, high stability, good $\mathrm{SO}_{2}$ tolerance and environmental friendliness that can be operated in low temperature and complex environment.

Research scholars at home and abroad have conducted in-depth and meticulous research on the deactivation research of SCR catalysts and found that the sulfur poisoning mechanism of the catalysts is different. At present, catalyst poisoning in an $\mathrm{SO}_{2}$ atmosphere is mainly carried out in three different ways. One thing is that $\mathrm{SO}_{2}$ in the flue gas has a competitive adsorption relationship with
This is an Open Access article distributed under the terms of the Creative Commons Attribution Non-Commercial License (http://creativecommons.org/licenses/by-nc/3.0/) which permits unrestricted non-commercial use, distribution, and reproduction in any medium, provided the original work is properly cited.

Copyright (C) 2022 Korean Society of Environmental Engineers
Received November 23, 2020 Accepted December 28, 2020

${ }^{\dagger}$ Corresponding author

E-mail: nmzhl@hotmail.com

Tel: +86-471-4991436

ORCID: 0000-0001-7991-6246 
$\mathrm{NO}_{\mathrm{x}}$ under the action of van der Waals force. The presence of $\mathrm{SO}_{2}$ will inhibit the adsorption of $\mathrm{NO}_{\mathrm{x}}$, which further hinders the occurrence of SCR reaction. This reaction is reversible inactivation, and the catalyst activity can be restored after the removal of adsorbed $\mathrm{SO}_{2}$ by means of thermal regeneration. In addition, the reaction of $\mathrm{SO}_{2}$ with the active component of the catalyst leads to the sulfation of the active center atom, thereby cutting off the redox cycle of the active phase, causing the catalyst to be poisoned and irreversible. Last but not least, $\mathrm{SO}_{2}$ reacts with $\mathrm{NH}_{3}$ to form ammonium sulfate salts, which are deposited on the surface of the catalyst, could block the adsorption site, catalytic active sites and pore structure on the surface of the catalyst, and result in irreversible inactivation of the catalyst.

So far, researchers have been using surface modification or cocatalyst doping to obtain more practical and cost-effective SCR catalysts, and have achieved encouraging results. Many scholars have reviewed the newly developed high-activity deNO ${ }_{x}$ catalysts, but there is a lack of research progress on the sulfur resistance of catalysts. Based on the SCR technology, this article focuses on the latest research progress in the strategy of improving the sulfur resistance of the catalyst during the deNO $\mathrm{x}_{\mathrm{x}}$ process, reveals the sulfur poisoning mechanism, and explains the regeneration process of the sulfur poisoning catalysts and the quantum chemistry in the field of sulfur resistance application. We hope this article will provide a reference for the optimization of existing catalysts and the development of SCR catalysts with excellent sulfur resistance in the future.

\section{Strategies to Enhance The Sulfur Resistance of Catalysts}

\subsection{Adding Functional Promoters}

\subsubsection{Fe modification}

Iron is usually used as an active ingredient or additive in catalysts $[5,6]$, due to its cheap raw materials, higher abundance, good reactivity and environmental friendliness. The d-orbital electrons of iron-based oxide are not saturated and can capture electrons, which has the potential of catalytic reduction of NO.

Kang et al. [5] prepared $\mathrm{Fe}_{2} \mathrm{O}_{3}$ modified $\mathrm{CeW} / \mathrm{H}$ catalyst and found that $\mathrm{Fe}_{2} \mathrm{O}_{3}$ doping can effectively suppress the irreversible combination of $\mathrm{SO}_{2}$ and active components. When the Fe-Ce molar ratio is 4 , the catalyst achieves the best $\mathrm{NO}_{\mathrm{x}}$ conversion rate and $\mathrm{SO}_{2}$ tolerance. After the material was continuously reacted in a $100 \mathrm{ppm} \mathrm{SO}_{2}$ atmosphere for 8 hours, the $\mathrm{NO}_{\mathrm{x}}$ conversion rate decreased by only $5 \%$. It is worth noting that the catalyst without Fe doping has a 50\% reduction in catalytic activity. The author used in situ Fourier transform spectroscopy to reveal the mechanism of action between $\mathrm{SO}_{2}$ and catalyst, as shown in Fig. 1. The results showed that there was competitive adsorption between $\mathrm{SO}_{2}$ and $\mathrm{NO}$ on the surface of $\mathrm{CeW} / \mathrm{H}$ sample. $\mathrm{SO}_{2}$ could react with the active component $\mathrm{CeO}_{2}$ to generate stable sulfate $\left(\mathrm{Ce}_{2}\left(\mathrm{SO}_{4}\right)_{3}\right)$ species, thus reducing the number of active sites and further inhibiting the reduction reaction. For Fe-modified catalysts, $\mathrm{SO}_{2}$ reacts with $\mathrm{Fe}_{2} \mathrm{O}_{3}$ to produce $\mathrm{Fe}_{2}\left(\mathrm{SO}_{4}\right)_{3}$, which can protect the active component $\mathrm{CeO}_{2}-\mathrm{WO}_{3}$ from being affected. Furthermore, the team [7] recently

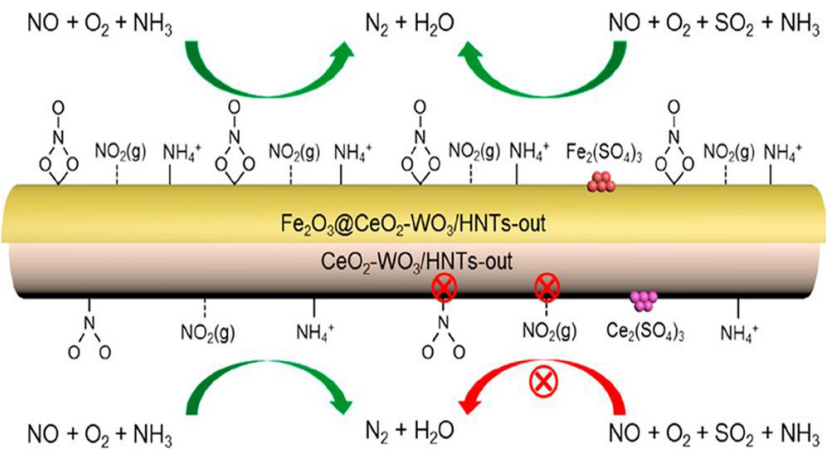

Fig. 1. The mechanism of $\mathrm{NO}_{x}$ reduction in the presence of $\mathrm{SO}_{2}$ over Fe@CeW/H and CeW/H catalysts [5].

claimed that $\mathrm{Fe}$-doped $\mathrm{CeVO}_{4}$ catalyst can significantly inhibit the adsorption of $\mathrm{SO}_{2}$ and sulfate species deposition for operating temperatures at $240^{\circ} \mathrm{C}$ compared to $\mathrm{CeVO}_{4}$ ones. Zeng et al. [8] explored the promotion of $\mathrm{Fe}^{3+}$ ions on $\mathrm{NH}_{3}$-SCR activity of $\mathrm{CePO}_{4}$ catalyst, and found that $\mathrm{Fe}^{3+}$ doping can induce $\mathrm{Fe}^{3+}+\mathrm{Ce}^{3+} \varsigma \mathrm{Fe}^{2+}+\mathrm{Ce}^{4+}$ redox balance, thereby significantly improving the redox performance of $\mathrm{CePO}_{4}$ catalyst. For $\mathrm{Fe}_{0.3} \mathrm{Ce}_{0.7}$ sample, after exposing to $5 \mathrm{vol} \% \mathrm{H}_{2} \mathrm{O}$ and $100 \mathrm{ppm} \mathrm{SO}_{2}$ for $10 \mathrm{~h}$, the deNO efficiency remained at $35.5 \%$, but the activity of $\mathrm{CePO}_{4}$ sample almost completely disappeared after $4 \mathrm{~h}$.

Jia et al. [9] synthesized a novel Fe-Sb binary metal oxide catalyst by ethylene glycol assisted co-precipitation technique. The $\mathrm{Fe}_{0.7} \mathrm{Sb}_{0.3} \mathrm{O}_{\mathrm{x}}$ catalyst showed good $\mathrm{NH}_{3}$-SCR activity with $100 \%$ conversion of $\mathrm{NO}_{\mathrm{x}}$ from $175^{\circ} \mathrm{C}$ to $250^{\circ} \mathrm{C}$ and high $\mathrm{SO}_{2} / \mathrm{H}_{2} \mathrm{O}$ durability at $250^{\circ} \mathrm{C}$. Wang et al. [10] developed iron-tungsten catalysts, which obtained above $90 \%$ NO removal efficiency within a wide operating temperature window. Results also showed pronounced stability and relatively high $\mathrm{NO}_{\mathrm{x}}$ conversion in the presence of $\mathrm{H}_{2} \mathrm{O}, \mathrm{SO}_{2}$ and $\mathrm{CO}_{2}$

$\mathrm{Li}$ et al. [11] confirmed that the main reasons for the deactivation of $\mathrm{Fe}_{10-\mathrm{x}} \mathrm{V}_{\mathrm{x}}$ binary metal oxides in $3 \mathrm{DOM}$ structures were the deposition of $\mathrm{NH}_{4} \mathrm{HSO}_{4}$ on the catalyst surface and the weakening or destruction of Brønsted acid potential. Zhu et al. [12] showed that after injecting $\mathrm{SO}_{2}$ and $\mathrm{H}_{2} \mathrm{O}$ into the reaction system for 24 hours, Fe-V-Ti catalyst remained above $93 \% \mathrm{NO}_{\mathrm{x}}$ conversion rate at $250^{\circ} \mathrm{C}$, and the catalytic efficiency restored to $100 \%$ after removal.

Dong et al. [13] showed that the Brønsted and Lewis acid content in Ti-PILc catalyst increased after Fe loading, and $\mathrm{H}_{2} \mathrm{O}(\mathrm{g})$ and $\mathrm{SO}_{2}$ had little influence on $\mathrm{C}_{3} \mathrm{H}_{6}$-SCR reaction. Qian et al. [14] also confirmed that Fe doping could improve the conversion rate of $\mathrm{NO}$ and $\mathrm{C}_{3} \mathrm{H}_{6}$ and the selectivity of $\mathrm{N}_{2}$. Sulfur dioxide and water vapor had little effect on the catalytic activity of Fe/Al-PILC. Wang et al. [15] pointed out that an increase in Fe content is beneficial to the conversion of $\mathrm{CO}$ and $\mathrm{NO}$ adsorbed on the catalyst surface $\left(\mathrm{NO} \rightarrow \mathrm{M}-\mathrm{NO}_{2} \rightarrow \mathrm{NO}_{2}^{-} \rightarrow \mathrm{M}-\mathrm{N}_{2} \mathrm{O} / \mathrm{NO}_{3}^{-} \rightarrow \mathrm{N}_{2} \mathrm{O} / \mathrm{N}_{2} ; \mathrm{CO} \rightarrow \mathrm{COO}^{-}\right.$ $\rightarrow \mathrm{CO}_{3}{ }^{2-} \rightarrow \mathrm{CO}_{2}$ ). The $\mathrm{H}_{2} \mathrm{O}$ and $\mathrm{SO}_{2}$ resistance test results showed that an appropriate increase in the proportion of $\mathrm{Fe}$ will promote the resistance of $\mathrm{SO}_{2} / \mathrm{H}_{2} \mathrm{O}$. The mechanism is that $\mathrm{Fe}$ inhibited the formation of sulfate and generates more water adsorption sites, as well as Fe optimized the pore structure. Fang et al. [16] found that calcination temperature would affect the sulfur resistance of Fe-Mn-Zr catalyst, and FMZ-500 had better tolerance to 100 and 
200 ppm $\mathrm{SO}_{2}$ than other samples (Fig. S1). Wang et al. [17] reported by doping with $\mathrm{Fe}$ on $\mathrm{Mn} / \gamma-\mathrm{Al}_{2} \mathrm{O}_{3}$ catalyst, the sulfate formation of $\mathrm{Mn}$ active component can be dramatically reduced and lower the stability of surface sediments $\left(\mathrm{NH}_{4} \mathrm{SO}_{4}\right)$, forcing them to decompose rapidly. Xie et al. [18] fabricated mesoporous $\gamma$ - $\mathrm{Fe}_{2} \mathrm{O}_{3}$-modified nanoflower- $\mathrm{MnO}_{2}$ /attapulgite catalyst through a facile hydrothermal method, which can effectively inhibit $\mathrm{SO}_{2}$ and $\mathrm{H}_{2} \mathrm{O}$ poisoning.

\subsubsection{Ce modification}

$\mathrm{CeO}_{2}$ has attracted much attention in the field of heterogeneous catalysis due to its excellent redox properties and oxygen storage capacity. It stores and releases oxygen through oxidation-reduction changes between $\mathrm{Ce}^{4+} / \mathrm{Ce}^{3+}$ under oxidation and reduction conditions, so that the catalyst can obtain more chemisorbed oxygen under oxygen-rich or oxygen-depleted conditions, further improving the dispersion of active ingredients on the catalyst surface [19]. In addition, the anti- $\mathrm{SO}_{2}$ poisoning ability improved after adding additive Ce. There are two main reasons. On the one hand, the cerium element will form a M-O-Ce solid solution with other metal elements on the surface of the catalyst, enhancing the Lewis acidity of the catalyst, thereby inhibiting the adsorption of acid gas $\mathrm{SO}_{2}$. On the other hand, the addition of cerium reduces the stability of sulfate species and weakens its deposition on the catalyst surface.

In research has been done by Chen et al. [20], a high-performance denitrification catalyst was synthesized based on Mn-Ce mixed oxide derived from a specific $\mathrm{Mn} / \mathrm{Ce}$ precursor. Compared to $\mathrm{MnO}_{\mathrm{x}}$, the new Mn-Ce mixed oxides delivered a much better $\mathrm{SO}_{2}$ tolerance, the $\mathrm{NO}_{x}$ conversion increased from $92.6 \%$ to $97.8 \%$ at $150^{\circ} \mathrm{C}$ when pouring into $200 \mathrm{ppm} \mathrm{SO}_{2}$. Wang et al. [21] carefully designed and synthesized $\mathrm{CeO}_{2}$ modified $\mathrm{MnCoCeO}_{x}$ catalysts for $\mathrm{NH}_{3}-\mathrm{SCR}$ reaction, and found that the modified catalyst has significantly enhanced low temperature deNO${ }_{x}$ activity and $\mathrm{SO}_{2}$ tolerance. The results showed that $\mathrm{MnCoO}_{\mathrm{x}}$ samples after $\mathrm{NH}_{3}$-SCR reaction for 12 hours in the presence of $50 \mathrm{ppm} \mathrm{SO}_{2}$ and $5 \mathrm{vol} \% \mathrm{H}_{2} \mathrm{O}$ contained more metal sulfate substances than $\mathrm{MnCoCeO}_{x}$, which proved that the former was more likely to be sulfurized as metal sulfate. In other words, the added $\mathrm{CeO}_{2}$ acts as a protective layer on the surface of the $\mathrm{MnCoO}_{\mathrm{x}}$ catalyst, which can prevent the active site of the $\mathrm{MnCoO}_{\mathrm{x}}$ material from being poisoned by $\mathrm{SO}_{2}$. Fan et al. [22] also proved that the addition of cerium oxide can inhibit the deposition of $\mathrm{NH}_{4} \mathrm{HSO}_{4}$ and preferentially react with $\mathrm{SO}_{2}$ to protect the active center.

Zhang et al. [23] reported that the effect of $\mathrm{SO}_{2}$ on $\mathrm{NO}$ conversion is greatly dependent on the reaction temperature over the $\mathrm{Ce}-\mathrm{TiO}_{2}$ catalyst. With the increase of reaction temperature, the tolerance of $\mathrm{SO}_{2}$ is gradually improved. Using catalyst performance measurements, after 8 hours of $\mathrm{SO}_{2}$ poisoning at $300^{\circ} \mathrm{C}$, the $\mathrm{NO}$ conversion rate decreased from $96.9 \%$ to $91.1 \%$, and remained unchanged after $\mathrm{SO}_{2}$ was cut off. The superior SCR activity of $\mathrm{Ce}-\mathrm{TiO}_{2}$ catalyst in the presence of $\mathrm{SO}_{2}$ at a higher reaction temperature may be attributed to the synergistic effect of cerium sulfate and bulk $\mathrm{CeO}_{2}$. Cerium sulfate acts as the acidic site for $\mathrm{NH}_{3}$ adsorption and $\mathrm{CeO}_{2}$ acts as the redox site. The DRIFT study has found that the formation of sulfate/cerium sulfite on the catalyst surface will inhibit the E-R and L-H pathways of the SCR reaction (as shown in Fig. 2).



Route I :

(E-R)

Low temperature

$\left(<200^{\circ} \mathrm{C}\right)$

Middle temperature: $\left(200^{\circ} \mathrm{C}-300^{\circ} \mathrm{C}\right)$

Route II :
(Proposed)

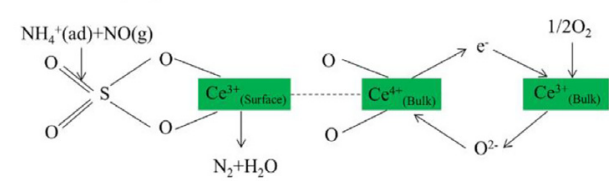

Fig. 2. The reaction mechanism for $\mathrm{SO}_{2}$ poisoning at low and middle temperatures [23].

Kwon et al. [24] investigated the influence of $\mathrm{SO}_{2}$ on the SCR process of Ce modified $\mathrm{V} / \mathrm{Sb} / \mathrm{Ce} / \mathrm{Ti}$ catalyst, and observed that $\mathrm{NH}_{4} \mathrm{HSO}_{4}$ could be formed on the surface of $\mathrm{V} / \mathrm{Sb} / \mathrm{Ti}$ (or $\mathrm{V} / \mathrm{W} / \mathrm{Ti}$ ) catalyst due to $\mathrm{SO}_{2}$ in the flue gas being oxidized to $\mathrm{SO}_{3}$, which would result in the blockage of catalyst pore. However, Ce in the modified catalyst reacts with $\mathrm{SO}_{2}$ and $\mathrm{O}_{2}$ to form $\mathrm{Ce}_{2}\left(\mathrm{SO}_{4}\right)_{3}$, which consumes $\mathrm{SO}_{2}$ and thus inhibits the formation of $\mathrm{NH}_{4} \mathrm{HSO}_{4}$. Therefore, the incorporation of Ce can improve the sulfur resistance of the catalyst. This study further confirmed the protective effect of Ce.

Shu et al. [25] developed a $\mathrm{Ce}-\mathrm{Fe} / \mathrm{TiO}_{2}$ supported metal honeycomb monolithic catalyst, which exhibited good anti-sulfur performance within $100 \mathrm{~h}$. In addition, sulfation can lead to the enrichment of $\mathrm{Ce}^{3+}$ on the surface of the catalyst and generate a large number of Brønsted acid sites. The mechanism study showed that the $\mathrm{NH}_{3}$-SCR reaction follows the Eley-Rideal (E-R) mechanism in the case of the sulfated catalysts. Ma et al. [26] also concluded that the $\mathrm{Cu}_{0.02} \mathrm{Fe}_{0.2}-\mathrm{Ce}_{0.2} \mathrm{Ti}_{0.8} \mathrm{O}_{\mathrm{x}}$ catalyst has excellent $\mathrm{H}_{2} \mathrm{O}$ and $\mathrm{SO}_{2}$ resistance after modifying with appropriate cerium.

\subsection{Choosing Suitable Carriers}

Numerous studies have shown that a suitable carrier both provide a surface for dispersing active ingredients, and a space for catalytic reactions. In addition, optimizing the interaction between the carrier and active components may improve the $\mathrm{SO}_{2}$ poisoning in SCR reaction.

Yao et al. [27] studied the denitrification performance of $\mathrm{CeO}_{2}-\mathrm{TiO}_{2}$ catalysts supported by $\mathrm{TiO}_{2}$ with different crystal structures. It was observed that the catalysts supported on rutile $\mathrm{TiO}_{2}$ had better denitrification performance than those supported on anatase or brookite $\mathrm{TiO}_{2}$, which were ascribed to the rich acid site, $\mathrm{Ce}^{3+}$ ions, adsorbed oxygen species and improved redox capacity. In addition, $\mathrm{CeO}_{2}-\mathrm{TiO}_{2}$ catalyst with $\mathrm{CeO}_{2}$ as the carrier has superior $\mathrm{SO}_{2}$ tolerance than only $\mathrm{TiO}_{2}$ carrier. The reasonable reason for this result is loading of $\mathrm{TiO}_{2}$ on the surface of $\mathrm{CeO}_{2}$ can restrain the sulfation of bulk $\mathrm{CeO}_{2}$, thus maintaining the redox ability. $\mathrm{NH}_{3}$-SCR reaction can take place through the synergistic effect of bulk $\mathrm{CeO}_{2}$ and surface sulfates. Liu et al. [28] put forward 
that the $\mathrm{NO}_{\mathrm{x}}$ conversion and $\mathrm{SO}_{2}$ resistance was well enhanced when $\mathrm{TiO}_{2}$ supporter adding to $\mathrm{ZrO}_{2}$. Researchers found that the surface area of the supporter would be enormously increased by introducing $\mathrm{TiO}_{2}$, thus the active components $\left(\mathrm{Fe}_{2} \mathrm{O}_{3}\right.$ and $\left.\mathrm{SO}_{4}{ }^{2-}\right)$ are highly dispersed on the support of binary metal oxides $\left(\mathrm{TiO}_{2}\right.$ $\mathrm{ZrO}_{2}$ ). Compared with single $\mathrm{TiO}_{2}$ or $\mathrm{ZrO}_{2}$, the interaction between $\mathrm{Ti}$ and $\mathrm{Zr}$ will significantly improve the conversion of $\mathrm{Fe}^{3+}$ to $\mathrm{Fe}^{2+}$ on Ti1Zr4 carrier.

$\mathrm{Li}$ et al. [29] found that the catalyst $\left(\mathrm{MnCeO} \times / \mathrm{TiO}_{2}-\mathrm{Al}_{2} \mathrm{O}_{3}\right)$ adding $\mathrm{Al}_{2} \mathrm{O}_{3}$ supporter presents higher SCR performance and $\mathrm{SO}_{2}$ poisoning tolerance than $\mathrm{MnCeO}_{x} / \mathrm{TiO}_{2}$ alone. Wang et al. [30] advocated that the sulfur tolerance of the $\mathrm{NbOPO}_{4}$ supported $\mathrm{Cu}$-Ce sample was greatly improved compared to $\mathrm{TiO}_{2}$ and $\mathrm{Ti}-\mathrm{Nb}$ supported samples. Cu-Ce/Nb-P sample has shown above $80 \% \mathrm{NO}$ removal efficiency after reaction for $10 \mathrm{~h}\left(250^{\circ} \mathrm{C}, 100 \mathrm{ppm} \mathrm{SO}\right)$. The excellent properties were owing to the increase of acidity and the strong interaction between $\mathrm{Cu}-\mathrm{Ce}$ oxides and $\mathrm{NbOPO}_{4}$ support, which avoided the surface oxygen species from being sulfurized by $\mathrm{SO}_{2}$. Wu et al. [31] proposed that the introduction of carbon nanotubes will be helpful to the improvement of sulfur resistance of catalysts.

\subsection{Regulation of Structure and Morphology}

Different synthesis methods of the catalysts will form different structures and morphologies, which will directly affect the inherent characteristics, the specific surface area, pore structure as well as the activity of the catalysts, and so on. The reasonable design of the catalysts with unique structure and morphology is an important method to protect the active substances from $\mathrm{SO}_{2}$ poisoning

Han et al. [32] compared the influence of the micromorphologies of $\mathrm{CeO}_{2}$ supports on the $\mathrm{NH}_{3}-\mathrm{SCR}$ reaction. The $\mathrm{Fe}_{2} \mathrm{O}_{3} / \mathrm{CeO}_{2}$ nanorods achieving higher catalytic activity than the $\mathrm{Fe}_{2} \mathrm{O}_{3} / \mathrm{CeO}_{2}$ nanopolyhedra and the NO conversion value still maintain 94\% during the whole test period whether inlet or cease $\mathrm{SO}_{2}$. Gao et al. [33] fabricated novel $\mathrm{Mn}-\mathrm{Ni}$ spinel nanosheets and attained $85-90 \%$ $\mathrm{NO}_{\mathrm{x}}$ conversion after introducing 10 vol\% $\mathrm{H}_{2} \mathrm{O}+150 \mathrm{ppm} \mathrm{SO}_{2}$ in the temperature regime between 150 and $300^{\circ} \mathrm{C}$. The higher SCR activity was attributed to two reasons: (1) the tetrahedral structure of spinel containing $\mathrm{Ni}$ avoids the sulfurization of $\mathrm{Mn}$ active sites wrapped in inner octahedron. (2) The morphology of the nanosheets hinders the adhesion of the sulfur ammonia component, thereby alleviating the deposition/inhibition effects.

$\mathrm{CeTiO}_{\mathrm{x}}$ catalysts with nanotube structure and high activity was reported by Zhang et al. [34], in which more than 98\% NO conversion can be got in the temperature range between $180^{\circ} \mathrm{C}$ and $390^{\circ} \mathrm{C}$. Moreover, after introducing $100 \mathrm{ppm} \mathrm{SO}_{2}$ and $6 \% \mathrm{H}_{2} \mathrm{O}$ at $240^{\circ} \mathrm{C}$, the NO conversion rate remained at about $96 \%$ within 8 hours. After closing $\mathrm{H}_{2} \mathrm{O}$ and $\mathrm{SO}_{2}$, the $\mathrm{NO}$ conversion rate can quickly return to the initial value. Huang et al. [35] developed a $\mathrm{V}_{2} \mathrm{O}_{5} / \mathrm{HWO}$ catalyst by support $\mathrm{V}_{2} \mathrm{O}_{5}$ on a hexagonal $\mathrm{WO}_{3}$ (HWO), which possess exceptional resistance simultaneously to alkalis and $\mathrm{SO}_{2}$ poisoning in the SCR reactions owning to the hexagonal structure of the HWO. Guo et al. [36] reported an interesting finding that regulating the pore size of the material contribute to decompose the deposited $\mathrm{NH}_{4} \mathrm{HSO}_{4}$. This team also found that the $\mathrm{Fe}_{2} \mathrm{O}_{3} / \mathrm{SBA}-15$ catalyst with larger mesopores exhibited much improved sulfur resistance, and quantitative analysis results demonstrated that the deposited sulfates was significantly relieved.



Fig. 3. The $\mathrm{SO}_{2}$ deactivation mechanism over $\mathrm{MnO}_{\mathrm{x}}-\mathrm{CeO}_{2} / \mathrm{TiO}_{2}$ and $\mathrm{MnO}_{\mathrm{x}}-\mathrm{CeO}_{2} @ \mathrm{TiO}_{2}$ catalysts [39].

Sheng et al. [37] found that the core-shell structure can protect the catalytic active sites from the effects of $\mathrm{H}_{2} \mathrm{O}$ and $\mathrm{SO}_{2}$ poisoning. The $\mathrm{SO}_{2}$ tolerance of $\mathrm{MnO}_{\mathrm{x}} @ \mathrm{TiO}_{2}$ core-shell nanorods is higher than that of $\mathrm{MnO}_{\mathrm{x}}$ and $\mathrm{MnO}_{\mathrm{x}} / \mathrm{TiO}_{2}$ catalysts, which is due to $\mathrm{SO}_{2}$ can be effectively isolated on the $\mathrm{TiO}_{2}$ shell. Gan et al. [38] explored the $\alpha-\mathrm{MnO}_{2} @ \mathrm{CeO}_{2}$ catalyst with a core-shell structure and found that the $\mathrm{CeO}_{2}$ shell can bind to $\mathrm{SO}_{2}$ firmly in preference to $\mathrm{MnO}_{2}$, and protect the active sites on the $\alpha-\mathrm{MnO}_{2}$ core from $\mathrm{SO}_{2}$ poisoning. Ma et al. [39] also proved that $\mathrm{MnO}_{\mathrm{x}}-\mathrm{CeO}_{2} @ \mathrm{TiO}_{2}$ core-shell composites showing the excellent SCR activity in the presence of $\mathrm{SO}_{2}$ than conventional $\mathrm{MnO}_{\mathrm{x}}-\mathrm{CeO}_{2} / \mathrm{TiO}_{2}$ catalysts. The $\mathrm{SO}_{2}$ deactivation mechanism over above catalysts are as follows (Fig. 3). Zhang et al. [40] proved that for the $\mathrm{SiO}_{2} @ \mathrm{FeCeO}_{x} / \mathrm{CNT}$ core-shell catalyst, the coated $\mathrm{SiO}_{2}$ shell establish an available barrier to hinder the generation of $\mathrm{FeSO}_{4}$ and restrain the reduction of chemisorbed oxygen, improving its stability and $\mathrm{SO}_{2}$ tolerance.

$\mathrm{Yu}$ et al. [41] designed and fabricated a novel $\mathrm{MnO}_{\mathrm{x}} @ \mathrm{Eu}-\mathrm{CeO}_{\mathrm{x}}$ catalyst with composite-shell structure and attained more than $95 \% \mathrm{NO}_{\mathrm{x}}$ conversion at low temperature $\left(100^{\circ} \mathrm{C}\right)$. The formation of the composite-shell structure enhanced the surface acidity and redox performance of catalyst, resulting in outstanding catalytic activity. When $\mathrm{SO}_{2}$ was introduced into the reaction for $4 \mathrm{~h}$, the $\mathrm{NO}_{\mathrm{x}}$ removal rate only declined from $93.7 \%$ to $91.0 \%$. Notably, when the $\mathrm{SO}_{2}$ flow in the simulated flue gas was cut off, the denitrification activity of the catalyst was almost completely recovered, this means that the major active components in the catalyst may not be irreversibly affected. The author drawn a conclusion that the protection of the $\mathrm{EuO}_{\mathrm{x}}-\mathrm{CeO}_{\mathrm{x}}$ composite-shell can reduce the toxicity of $\mathrm{SO}_{2}$ to $\mathrm{Mn}$ active sites and the strong interaction between the Ce and Mn can effectively limited the deposition of the surface sulphates (as shown in Fig. S2) Cai et al. [42] designed multi-shell $\mathrm{Fe}_{2} \mathrm{O}_{3} @ \mathrm{MnO}_{\mathrm{x}} @ \mathrm{CNT}$ catalysts, which also proved that the $\mathrm{Fe}_{2} \mathrm{O}_{3}$ shell could effectively suppress the formation of the surface sulfate species.

\subsection{Establishing a Dynamic Equilibrium between Sulfate Formation and Decomposition}

Lately, the research team of Zhejiang University [43] proposed new countermeasures to enhance the sulfur dioxide tolerance of 




Fig. 4. The deposition and decomposition of surface sulfate are in a dynamic equilibrium over catalysts [43].

SCR catalyst - by establishing a dynamic equilibrium between sulfates formation and decomposition. This team designed a novel $\mathrm{MnO}_{x} / \mathrm{CeO}_{2}$ nanorod catalyst with the assistance of key information obtained from TEM experiments and first-principles calculations. The catalysts showed almost no activity loss with an apparent $\mathrm{NO}_{\mathrm{x}}$ reaction rate of $1,800 \mu \mathrm{mol} \mathrm{g}{ }^{-1} \mathrm{~h}^{-1}$ for $1000 \mathrm{~h}$ test at $250^{\circ} \mathrm{C}$ in the presence of $200 \mathrm{ppm} \mathrm{SO}_{2}$. They found that the deposition and decomposition of surface sulfate are in a dynamic equilibrium over $\mathrm{CeO}_{2}(\mathrm{NR})$ and $\mathrm{MnO}_{x} / \mathrm{CeO}_{2}(\mathrm{NR})$, which can suppress the accumulation of sulfate and keep the exceedingly good activity at low temperature, the reactions involved in the establishment of surface formation and decomposition as shown below (Fig. 4): $2 \mathrm{CeO}_{2}+3 \mathrm{SO}_{2}+\mathrm{O}_{2} \rightarrow \mathrm{Ce}_{2}\left(\mathrm{SO}_{4}\right)_{3}, \mathrm{Ce}_{2}\left(\mathrm{SO}_{4}\right)_{3}+4 \mathrm{NH}_{3}+3 \mathrm{H}_{2} \mathrm{O} \rightarrow$ $\mathrm{Ce}_{2} \mathrm{O}_{3}+\left(\mathrm{NH}_{4}\right)_{2} \mathrm{SO}_{4}+2 \mathrm{NH}_{4} \mathrm{HSO}_{4}, \mathrm{Ce}_{2} \mathrm{O}_{3}+1 / 2 \mathrm{O}_{2} \rightarrow 2 \mathrm{CeO}_{2},\left(\mathrm{NH}_{4}\right)_{2} \mathrm{SO}_{4}+$ $2 \mathrm{NH}_{4} \mathrm{HSO}_{4}+2 \mathrm{NO}+1 / 2 \mathrm{O}_{2} \rightarrow 3 \mathrm{~N}_{2}+9 \mathrm{H}_{2} \mathrm{O}+3 \mathrm{SO}_{2}$.

\subsection{The Improvement Strategy of Several Classic Catalysts}

\subsubsection{Vanadium-based catalysts}

Vanadium-based catalysts have been predominantly used as commercial catalysts with the operating temperature concentrated at $300-400^{\circ} \mathrm{C}$. However, some drawbacks of this type of catalysts including narrow working temperature window $\left(300-400^{\circ} \mathrm{C}\right)$ and susceptible to deactivation by residual $\mathrm{SO}_{2}$ in the exhaust. The characteristics of actual flue gas are low temperatures and high $\mathrm{SO}_{2}$ content which conventional vanadium-based catalysts cannot handle. Therefore, the resistance to sulfur poisoning of the catalyst need to be further improved to satisfy the practical application.

Liang et al. [44] put forward that adding moderate $\mathrm{F}$ ions would erode the surface morphology of the catalyst and reduce its particle size, so as to improve the NO conversion rate at low temperature and the sulfur and water resistance of $\mathrm{V}_{2} \mathrm{O}_{5}-\mathrm{WO}_{3} / \mathrm{TiO}_{2}$ catalyst. Kang et al. [45] reveals the reason for sample obtained after the physical mixing of $\mathrm{V}_{2} \mathrm{O}_{5}-\mathrm{WO}_{3} / \mathrm{TiO}_{2}$ with several $\mathrm{Fe}_{2} \mathrm{O}_{3}$ has superior performance through a series of representational means $\left(\mathrm{SO}_{2}-\mathrm{TPD}\right.$, $\mathrm{NH}_{3}$-TPD and in situ FT-IR), which attributable to the following two reasons: (1) $\mathrm{Fe}_{2} \mathrm{O}_{3}$ adjacent to $\mathrm{V}_{2} \mathrm{O}_{5}-\mathrm{WO}_{3} / \mathrm{TiO}_{2}$ inhibited the formation of $\mathrm{NH}_{4} \mathrm{SO}_{4}$ by generating $\mathrm{FeSO}_{4}$ (2) The formation of $\mathrm{FeSO}_{4}$ provides additional Brønsted acid sites, which promotes the conversion of $\mathrm{NO}_{\mathrm{x}}$. The mechanism of sulfate species formation over catalysts was illustrated in Fig. S3.

Team of Professor Li from Dalian University of Technology [46] proposed that the sulfation tends to have a negative effect on the low-temperature reaction of $\mathrm{FeVO}_{\mathrm{x}}$ catalyst, but actively promotes high-temperature activity by inhibiting harmful $\mathrm{NH}_{3}$ oxidation. $\mathrm{Li}$ et al. [47] found that $\mathrm{V}-\mathrm{W} / \mathrm{Ce} / \mathrm{Ti}-5 \%$ presented better $\mathrm{NH}_{3}-\mathrm{SCR}$ activity and higher $\mathrm{NH}_{4} \mathrm{HSO}_{4}$ resistance at $280^{\circ} \mathrm{C}$ when $5 \% \mathrm{WO}_{3}$ was loaded. The result is due to $\mathrm{WO}_{3}$ doping suppresses the formation of $\mathrm{NH}_{4} \mathrm{HSO}_{4}$ and metal sulfate species over active sites by lowering the alkalinity of $\mathrm{V}-\mathrm{W} / \mathrm{Ce} / \mathrm{Ti}-5 \%$.

\subsubsection{Manganese-based catalysts}

Manganese-based catalysts have been widely used in recent years on account of their variable valence, remarkable redox capabilities, rich Lewis acid sites, and excellent low-temperature catalytic activity. However, for a single $\mathrm{MnO}_{\mathrm{x}}$ catalyst, poor resistance to $\mathrm{SO}_{2}$ is the main challenge that hinders its further industrial application [48]. The Li Junhua team [49] reported that exposing to 150 ppm $\mathrm{SO}_{2}$ at $150^{\circ} \mathrm{C}$, the $\mathrm{NO}$ conversion rate of pure $\mathrm{MnO}_{\mathrm{x}}$ decreased from $92 \%$ to $23 \%$, and only recovered to $45 \%$ after cutting off $\mathrm{SO}_{2}$. Due to the strong oxidation ability of $\mathrm{Mn}$ oxide, $\mathrm{SO}_{2}$ is easily oxidized to $\mathrm{SO}_{3}$ at low temperature, and the formed $\mathrm{SO}_{3}$ reacts with $\mathrm{NH}_{3}$ or active components to form sulfate, which can cover the surface of the catalyst, block the pore of the catalyst, and inhibit the contact between the catalyst and reaction molecules, thus causing the catalyst deactivation. Therefore, preventing or reducing $\mathrm{SO}_{2}$ poisoning of Mn-based catalyst has become the focus of academic and industrial attention. More and more studies show that introducing another phase as sacrificial agent to capture $\mathrm{SO}_{2}$ in priority can improve the anti-sulfur performance of Mn-based catalyst.

Jiang et al. [50] synthesized some $\alpha-\mathrm{MnO}_{2}$ catalysts doped with $\mathrm{Fe}, \mathrm{Ce}, \mathrm{Cr}, \mathrm{Zr}$ or Co as metal co-catalysts by hydrothermal method, and found that the catalysts doped with Co showed the best low temperature $\mathrm{NH}_{3}$-SCR activity and excellent $\mathrm{H}_{2} \mathrm{O} / \mathrm{SO}_{2}$ tolerance. $\mathrm{NO}$ conversion activity remained at $100 \%$ at $200^{\circ} \mathrm{C}$ when $\mathrm{H}_{2} \mathrm{O}$ and $\mathrm{SO}_{2}$ exists in the flue gas. Sun et al. [51] prepared a series of $\mathrm{MnNb} / \mathrm{TiO}_{2}$ catalyst samples with different $\mathrm{Nb} / \mathrm{Mn}$ molar ratios using the sol-gel method, and studied the effect of $\mathrm{SO}_{2}$ on the denitrification process. The experimental results show that introducing $\mathrm{Nb}$ into the $\mathrm{Mn} / \mathrm{TiO}_{2}$ catalyst can increase the specific surface area, enhance the reducibility and surface acidity, promote the formation of more $\mathrm{Mn}^{4+}$ and chemically adsorbed oxygen on its surface, and produce more $\mathrm{NO}_{2}$. Liu et al. [52] found that $\mathrm{MnEu} / \mathrm{TiO}_{2}$ catalyst also had excellent $\mathrm{SO}_{2}$ resistance performance. Through in-situ infrared technology, it was found that $\mathrm{SO}_{2}$ could promote the adsorption of $\mathrm{NH}_{3}$ and inhibit the adsorption of $\mathrm{NO}_{\mathrm{x}}$. Eu modification could partially offset the inhibition effect of $\mathrm{SO}_{2}$ on the adsorption of $\mathrm{NO}_{\mathrm{x}}$ on $\mathrm{Mn} / \mathrm{TiO}_{2}$ catalyst.

The research team of Huazhong University of Science and Technology [53] found that the presence of Sm promotes the anti-SO performance of the $\mathrm{Mn} / \mathrm{TiO}_{2}$ catalyst. The electron transfer between $\mathrm{Sm}$ and $\mathrm{Mn}$ ions inhibits the oxidation of $\mathrm{SO}_{2}$, thereby inhibiting the formation of sulfate (Fig. S4). Wang et al. [54] also demonstrated the superiority of the Sm modified catalyst. Compared with catalysts without $\mathrm{Sm}$, mesoporous $\mathrm{MnCeSmTiO}_{\mathrm{x}}$ mixed oxides maintained higher catalytic performance after $\mathrm{H}_{2} \mathrm{O}$ and $\mathrm{SO}_{2}$ were added by 
suppressing the oxidation of $\mathrm{SO}_{2}$ by $\mathrm{Mn}^{4+}$ and $\mathrm{Ce}^{4+}$. Zhang et al. [55] found that when $200 \mathrm{ppmV} \mathrm{SO}_{2}$ was introduced into the feed gas, the catalytic activity of $\mathrm{Sb}$ modified $\mathrm{Mn} / \mathrm{PG}$ catalyst was reduced by only $1 \%$, while the NO conversion rate of unmodified catalyst was reduced by nearly $60 \%$.

Liu et al. [56] claimed that graphite carbon has a positive role in improving the anti- $\mathrm{SO}_{2}$ performance of Mn-based catalysts, thanks to its assembly structure, small grain crystals, high specific surface area and appropriate oxidation capacity. The $\mathrm{Mn}_{3} \mathrm{O}_{4}$-A catalyst was reduced from $98 \%$ conversion rate to $13 \%$ within 8 hours, while the $\mathrm{Mn}_{3} \mathrm{O}_{4} @ \mathrm{GA}$ catalyst was able to maintain 80\% catalytic activity under $\mathrm{H}_{2} \mathrm{O}$ and $\mathrm{SO}_{2}$ atmosphere. XPS and He-TPD characterization results show that the sulfate species on the surface of $\mathrm{Mn}_{3} \mathrm{O}_{4}$-A are mainly formed by the reaction between $\mathrm{Mn}_{3} \mathrm{O}_{4}$ and $\mathrm{SO}_{3}$ and the decomposition products of $\mathrm{NH}_{4} \mathrm{HSO}_{4}$, but no obvious sulfates were found on the surface of the $\mathrm{Mn}_{3} \mathrm{O}_{4} @ \mathrm{GA}$ catalyst. It is proved that the weakening of the oxidation ability of $\mathrm{Mn}_{3} \mathrm{O}_{4} @ \mathrm{GA}$ can inhibit the oxidation of $\mathrm{SO}_{2}$ to $\mathrm{SO}_{3}$ and avoid the formation of $\mathrm{NH}_{4} \mathrm{HSO}_{4}$, thereby further improving the performance of anti- $\mathrm{SO}_{2}$. Fan et al. [57] found that $\mathrm{Al}_{2} \mathrm{O}_{3}$ is a promoter to enhance the sulfur resistance of $\mathrm{MnO}_{\mathrm{x}}$. The result indicates that $\mathrm{Al}_{2} \mathrm{O}_{3}$ can decrease the thermal stability of $\mathrm{NH}_{4} \mathrm{HSO}_{4}$ and the adsorbed $\mathrm{SO}_{2}$ species to some extent.
Gao et al. [58] prepared novel hydroxyl containing Co-Mn and Ni-Mn binary oxides by the combined complexation-esterification method to eliminate $\mathrm{NO}_{\mathrm{x}}$. The study found that the addition of Co and Ni elements increased the concentration of chemically adsorbed oxygen on the catalyst surface and the effective electron conversion of cations, which delayed the $\mathrm{SO}_{2}$ poisoning process. In addition, this team [59] also explored the influence of $\mathrm{SO}_{2}$ on the surface of $\mathrm{Mn}_{2} \mathrm{NiO}_{4}$ spinel catalyst on the reaction path, and further proved that the $\mathrm{Ni}$ modified $\mathrm{MnO}_{\mathrm{x}}$ catalyst had an extremely significant enhancement effect on the tolerance of $\mathrm{SO}_{2}$, which may be attributed to the special spinel structure. Xiong et al. [60] investigated the role of low-valent copper dopants in $\mathrm{Mn}_{3} \mathrm{O}_{4}$ spinel SCR catalysts. The study pointed out that the doping of copper element increases the specific surface area, active $\mathrm{Mn}^{4+}$ species and surface acid content of the spinel catalyst, thereby greatly improving the low-temperature SCR activity and $\mathrm{SO}_{2}$ tolerance. Under the combined action of $\mathrm{SO}_{2}$ and $\mathrm{H}_{2} \mathrm{O}\left(200^{\circ} \mathrm{C}\right)$, the $\mathrm{NO}_{\mathrm{x}}$ conversion rate only dropped by about $4 \%$ and remained at $87 \%$.

Yan et al. [61] prepared a new low-temperature $\mathrm{NH}_{3}$-SCR catalyst $\mathrm{Cu}_{\mathrm{w}} \mathrm{Mn}_{\mathrm{y}} \mathrm{Ti}_{1-\mathrm{y}} \mathrm{O}_{\mathrm{x}}$ from layered double hydroxides (LDHs) precursor. The study found that $\mathrm{Cu}_{1} \mathrm{Mn}_{0.5} \mathrm{Ti}_{0.5} \mathrm{O}_{\mathrm{x}}$ showed the optimal SCR performance, with a $\mathrm{NO}_{\mathrm{x}}$ conversion rate of $90 \%$ and $\mathrm{N}_{2}$ selectivity of $99.4 \%$ at $200^{\circ} \mathrm{C}$, which were much higher than the control catalyst

Table 1. Summary of SCR Catalysts with Strong Resistance to $\mathrm{SO}_{2}$

\begin{tabular}{|c|c|c|c|}
\hline Catalyst & Reaction condition & Catalytic activity & Ref. \\
\hline $\mathrm{Fe} @ \mathrm{CeW} / \mathrm{H}$ & $\begin{aligned} {[\mathrm{NO}]=} & {\left[\mathrm{NH}_{3}\right]=500 \mathrm{ppm},\left[\mathrm{SO}_{2}\right]=100 \mathrm{ppm},\left[\mathrm{O}_{2}\right]=5 \mathrm{vol} \%, \mathrm{~N}_{2} \text { balance } } \\
& \text { total gas flow rate }=250 \mathrm{~mL} / \mathrm{min}, \mathrm{GHSV}=40,000 \mathrm{~h}^{-1}\end{aligned}$ & $\begin{array}{c}93 \% \\
\left(200^{\circ} \mathrm{C}\right)\end{array}$ & {$[5]$} \\
\hline $\mathrm{Fe}_{0.1} \mathrm{~V}_{0.1} \mathrm{TiO}_{\mathrm{x}}$ & $\begin{array}{l}{[\mathrm{NO}]=\left[\mathrm{NH}_{3}\right]=500 \mathrm{ppm},\left[\mathrm{SO}_{2}\right]=100 \mathrm{ppm}\left[\mathrm{O}_{2}\right]=5 \mathrm{vol} . \%,\left[\mathrm{H}_{2} \mathrm{O}\right]=5 \mathrm{vol} . \%} \\
\mathrm{~N}_{2} \text { balance, total gas flow rate }=500 \mathrm{~mL} / \mathrm{min}, \mathrm{GHSV}=200,000 \mathrm{~h}^{-1}\end{array}$ & $\begin{array}{c}93 \% \\
\left(250^{\circ} \mathrm{C}\right)\end{array}$ & {$[12]$} \\
\hline $\mathrm{Mn}-\mathrm{Fe}-2 / \gamma-\mathrm{Al}_{2} \mathrm{O}_{3}$ & $\begin{array}{c}{\left[\mathrm{NO}_{\mathrm{x}}\right]=0.03 \%,\left[\mathrm{NH}_{3}\right]=0.033 \%,\left[\mathrm{SO}_{2}\right]=250 \mathrm{mg} / \mathrm{cm}^{3},\left[\mathrm{O}_{2}\right]=6 \mathrm{vol} . \%} \\
{\left[\mathrm{H}_{2} \mathrm{O}\right]=6 \text { vol. } \%, \mathrm{~N}_{2} \text { balance, GHSV }=6,000-14,000 \mathrm{~h}^{-1}}\end{array}$ & $\begin{array}{c}84 \% \\
\left(150^{\circ} \mathrm{C}\right)\end{array}$ & {$[17]$} \\
\hline$\gamma-\mathrm{Fe}_{2} \mathrm{O}_{3} / \mathrm{nf}-\mathrm{MnO}_{2}-\mathrm{ATP}$ & $\begin{array}{c}{[\mathrm{NO}]=\left[\mathrm{NH}_{3}\right]=1000 \mathrm{ppm},\left[\mathrm{SO}_{2}\right]=200 \mathrm{ppm}\left[\mathrm{O}_{2}\right]=3 \mathrm{vol} . \%, \mathrm{~N}_{2} \text { balance, }} \\
\text { total gas flow rate }=2 \mathrm{~L} / \mathrm{min}, \mathrm{GHSV}=45,000 \mathrm{~h}^{-1}\end{array}$ & $\begin{array}{c}89 \% \\
\left(200^{\circ} \mathrm{C}\right)\end{array}$ & [18] \\
\hline Mn/Ce-400-Air & $\begin{aligned} {[\mathrm{NO}]=\left[\mathrm{NH}_{3}\right]=500 \mathrm{ppm},\left[\mathrm{SO}_{2}\right] } & =200 \mathrm{ppm},\left[\mathrm{O}_{2}\right]=3 \mathrm{vol} \%, \mathrm{~N}_{2} \text { balance } \\
\mathrm{GHSV} & =52,500 \mathrm{~h}^{-1}\end{aligned}$ & $\begin{array}{l}97.8 \% \\
\left(150^{\circ} \mathrm{C}\right)\end{array}$ & {$[20]$} \\
\hline $\mathrm{Ce}-\mathrm{TiO}_{2}$ & $\begin{array}{c}{[\mathrm{NO}]=\left[\mathrm{NH}_{3}\right]=600 \mathrm{ppm},\left[\mathrm{SO}_{2}\right]=1000 \mathrm{ppm}^{-}\left[\mathrm{O}_{2}\right]=3 \mathrm{vol} \%, \mathrm{~N}_{2} \text { balance, }} \\
\mathrm{GHSV}=40,000 \mathrm{~h}^{-1}\end{array}$ & $\begin{array}{l}91.1 \% \\
\left(300^{\circ} \mathrm{C}\right)\end{array}$ & {$[23]$} \\
\hline FeS/(Ti1Zr4) & $\begin{aligned} {[\mathrm{NO}]=} & {\left[\mathrm{NH}_{3}\right]=500 \mathrm{ppm},\left[\mathrm{SO}_{2}\right]=200 \mathrm{ppm},\left[\mathrm{O}_{2}\right]=3 \mathrm{vol} \%, \mathrm{~N}_{2} \text { balance, } } \\
& \text { total gas flow rate }=300 \mathrm{~mL} / \mathrm{min}, \mathrm{GHSV}=47,000 \mathrm{~h}^{-1}\end{aligned}$ & $\begin{array}{c}96 \% \\
\left(300^{\circ} \mathrm{C}\right)\end{array}$ & [28] \\
\hline $\mathrm{Fe}_{2} \mathrm{O}_{3} / \mathrm{CeO}_{2}-\mathrm{NR}$ & $\begin{aligned} {[\mathrm{NO}]=} & {\left[\mathrm{NH}_{3}\right]=500 \mathrm{ppm},\left[\mathrm{SO}_{2}\right]=100 \mathrm{ppm},\left[\mathrm{O}_{2}\right]=3 \mathrm{vol} \%, \mathrm{~N}_{2} \text { balance } } \\
& \text { total gas flow rate }=250 \mathrm{~mL} / \mathrm{min}, \mathrm{GHSV}=20,000 \mathrm{~h}^{-1}\end{aligned}$ & $\begin{array}{c}94 \% \\
\left(275^{\circ} \mathrm{C}\right)\end{array}$ & {$[32]$} \\
\hline $\mathrm{NiMn}_{2} \mathrm{O}_{4}$-UHHS & $\begin{array}{c}{[\mathrm{NO}]=\left[\mathrm{NH}_{3}\right]=500 \mathrm{ppm},\left[\mathrm{SO}_{2}\right]=150 \mathrm{ppm},\left[\mathrm{O}_{2}\right]=5 \mathrm{vol} \%,\left[\mathrm{H}_{2} \mathrm{O}\right]=10 \mathrm{vol} . \%} \\
\mathrm{~N}_{2} \text { balance, total gas flow rate }=100 \mathrm{~mL} / \mathrm{min}, \mathrm{GHSV}=32,000 \mathrm{~h}^{-1}\end{array}$ & $\begin{array}{c}85-90 \% \\
\left(150-300^{\circ} \mathrm{C}\right)\end{array}$ & {$[33]$} \\
\hline $\mathrm{CeTiO}_{\mathrm{x}}-\mathrm{T}$ & $\begin{array}{c}{[\mathrm{NO}]=\left[\mathrm{NH}_{3}\right]=1000 \mathrm{ppm},\left[\mathrm{SO}_{2}\right]=100 \mathrm{ppm},\left[\mathrm{O}_{2}\right]=3 \mathrm{vol} \%,\left[\mathrm{H}_{2} \mathrm{O}\right]=6 \mathrm{vol} . \%} \\
\mathrm{~N}_{2} \text { balance, total gas flow rate }=200 \mathrm{~mL} / \mathrm{min}, \mathrm{GHSV}=40,000 \mathrm{~h}^{-1}\end{array}$ & $\begin{array}{c}96 \% \\
\left(240^{\circ} \mathrm{C}\right)\end{array}$ & {$[34]$} \\
\hline MnOx@Eu-CeOx & $\begin{array}{c}{[\mathrm{NO}]=\left[\mathrm{NH}_{3}\right]=600 \mathrm{ppm}, \quad\left[\mathrm{SO}_{2}\right]=100 \mathrm{ppm},\left[\mathrm{O}_{2}\right]=2.5 \mathrm{vol} \%, \text { Ar balance, }} \\
\text { GHSV }=90,000 \mathrm{~h}^{-1}\end{array}$ & $\begin{array}{c}91 \% \\
\left(200^{\circ} \mathrm{C}\right)\end{array}$ & {$[41]$} \\
\hline $\mathrm{MnO}_{2}-\mathrm{Co}-0.8$ & $\begin{array}{l}{[\mathrm{NO}]=\left[\mathrm{NH}_{3}\right]=500 \mathrm{ppm},\left[\mathrm{SO}_{2}\right]=100 \mathrm{ppm},\left[\mathrm{O}_{2}\right]=5 \mathrm{vol} \%,\left[\mathrm{H}_{2} \mathrm{O}\right]=5 \mathrm{vol} . \%} \\
\text { Ar balance, total gas flow rate }=100 \mathrm{~mL} / \mathrm{min}, \mathrm{GHSV}=50,000 \mathrm{~h}^{-1}\end{array}$ & $\begin{array}{l}100 \% \\
\left(200^{\circ} \mathrm{C}\right)\end{array}$ & {$[50]$} \\
\hline $\mathrm{Cu}-\mathrm{Ce} / \mathrm{SP}-0.75$ & $\begin{aligned} {[\mathrm{NO}]=} & {\left[\mathrm{NH}_{3}\right]=500 \mathrm{ppm},\left[\mathrm{SO}_{2}\right]=100 \mathrm{ppm},\left[\mathrm{O}_{2}\right]=5 \mathrm{vol} \%, \mathrm{~N}_{2} \text { balance, } } \\
& \text { total gas flow rate }=100 \mathrm{~mL} / \mathrm{min}, \mathrm{GHSV}=20,000 \mathrm{~h}^{-1}\end{aligned}$ & $\begin{array}{c}90 \% \\
\left(200-450^{\circ} \mathrm{C}\right)\end{array}$ & [65] \\
\hline
\end{tabular}


$\mathrm{Mn} / \mathrm{TiO}_{2}(80.7 \%, 88 \%)$ and $\mathrm{Cu}-\mathrm{Mn} / \mathrm{TiO}_{2}(86.1 \%, 95 \%)$ prepared by the traditional immersion method. The outstanding catalytic activity is closely related to its large specific surface area and surface acidity as well as abundant active substances $\left(\mathrm{MnO}_{2}\right.$ and $\left.\mathrm{CuO}\right)$. The addition of copper can increase the number of acid groups and strengthen $\mathrm{SO}_{2}$-resistence of Mn-based catalysts. By comparing the in-situ DRIFT spectra obtained by the catalyst exposed to $\mathrm{NO}_{\mathrm{x}}$ and $\mathrm{SO}_{2}$, the results show that there is a competitive relationship between $\mathrm{SO}_{2}$ and $\mathrm{NO}_{\mathrm{x}}$ on the surface adsorption sites. Significantly, the intensity of the peak attributable to the sulfur species on $\mathrm{Cu}_{1} \mathrm{Mn}_{0.5} \mathrm{Ti}_{0.5} \mathrm{O}_{\mathrm{x}}$ is higher than that of $\mathrm{Cu}-\mathrm{Mn} / \mathrm{TiO}_{2}$ It is much weaker than $\mathrm{Mn} / \mathrm{TiO}_{2}$, and the intensity attributable to the $\mathrm{NO}_{x}$ peak is the opposite, further proving the former's stronger sulfur resistance. Chen et al. [62] reported that a $\mathrm{Mn}_{1} \mathrm{Fe}_{0.25} \mathrm{Al}_{0.75} \mathrm{O}_{\mathrm{x}}$ catalyst obtained by calcining the $\mathrm{LDH}$ precursor also has excellent $\mathrm{SO}_{2}$ resistance. Zhou et al. [63] found that two-dimensional layered double oxide (LDO) catalyst $\mathrm{MnFeCo}$ obtained $100 \%$ deNO$_{x}$ efficiency at $100^{\circ} \mathrm{C}$, and $\mathrm{MnFeCo}-\mathrm{LDO}$ catalyst at $120^{\circ} \mathrm{C}$ had better water resistance (rehydroxylation) and sulfur dioxide resistance than $\mathrm{MnCo}-\mathrm{LDO}$ and MnFe-LDO samples.

\subsubsection{Zeolite catalysts}

Recently, ion-exchanged zeolites catalysts have aroused people's special attention for its outstanding catalytic performance with wide operation temperature window. Nevertheless, the deposition of $\left(\mathrm{NH}_{4}\right)_{2} \mathrm{SO}_{4}$ or $\mathrm{NH}_{4} \mathrm{NO}_{3}$ can block the pore/channel of the conventional microporous zeolites, resulting in the deactivation of the catalyst at low reaction temperature. Based on this, it is urgent to improve the zeolite catalyst.

Peng and his team [64] successfully developed hierarchical Cu-ZSM-5 zeolite with different structures (meso- and micro-pore). The study found that, compared with the conventional Cu-ZSM-5 catalyst (73\% NO conversion), the hierarchical Cu-ZSM-5 catalyst exhibits better denitrification efficiency with $93 \%$ NO conversion at $250^{\circ} \mathrm{C}$. The better performance on Cu-ZSM-5-meso can be attributed to its rich mesoporous structure, which can greatly promote the mass transfer process of reactants or products at low temperature. Furthermore, the $\mathrm{NO}_{\mathrm{x}}$ conversion rate of the new Cu-ZSM-5-meso catalyst below $350^{\circ} \mathrm{C}$ is higher than that of the conventional $\mathrm{Cu}-Z S M-5$ samples after introducing $100 \mathrm{ppm} \mathrm{SO}$ into reaction system, which may be due to the hierarchical structure of Cu-ZSM-5-meso can weaken the negative effect of sulfate species. $\mathrm{Ma}$ et al. [65] came up with a series of Cu-Ce co-doped SAPO-5/34 catalyst and discovered Cu-Ce/SP-0.75 can maintain more than
$90 \%$ SCR activity at $200-450^{\circ} \mathrm{C}$ after adding $100 \mathrm{ppm}$ of $\mathrm{SO}_{2}$.

Wan et al. [66] synthesized a series of Fe/Cu-SSZ-13 catalysts with different Fe loading content by simple one-pot method. compared with $\mathrm{Cu}-\mathrm{SSZ}-13, \mathrm{Fe}_{0.63} / \mathrm{Cu}_{1.50}$-SSZ-13 catalyst with proper Fe content present typical chabazite (CHA) structure and exhibit extraordinary catalytic activity from $160-580^{\circ} \mathrm{C}$, excellent hydrothermal stability as well as good resistance to sulfur toxicity. Yu et al. [67] prepared Cu-SSZ-13 molecular sieve complexes with different metal oxide components ( $\mathrm{Mn}, \mathrm{Co}, \mathrm{Ni}, \mathrm{Zn}$ ) via sol-dispersion method. The results showed that $\mathrm{ZnTi}_{10} \mathrm{O}_{\mathrm{x}}$ in the hybrid catalyst could be used as a sacrificial component to preferentially react with $\mathrm{SO}_{2}$, thus preventing the $\mathrm{Cu}^{2+}$ active site from sulfur inactivation.

According to the above contents, we can find that doping other substances to protect the active centers from sulfur poisoning is a promising method to strengthen the sulfur resistance of catalysts.

\section{Regeneration of Sulfur Poisoning Catalyst}

The development of deNO $\mathrm{O}_{\mathrm{x}}$ technology is accompanied by the problem of disposal of waste catalysts. At present, deactivated deNO catalysts are included in the field of hazardous waste in China. Therefore, how to dispose of waste catalysts rationally is a major problem. The regeneration of deNO ${ }_{x}$ catalysts is the only way for the development of deNO $\mathrm{N}_{\mathrm{x}}$ industry. Catalyst regeneration is an important way to recover the activity of deactivated catalyst, and the use of regenerated catalyst is conducive to saving raw materials, realizing the recycling of limited resources, and greatly reducing the cost of SCR technology. In addition, it can avoid secondary pollution of the environment, protect the environment and implement the concept of sustainable development.

\subsection{Thermal Regeneration Method}

Thermal regeneration refers to the roasting of the catalyst at a certain temperature. The regeneration of the catalyst depends upon whether the heat treatment can eliminate $\mathrm{NH}_{4} \mathrm{HSO}_{4}$ and $\mathrm{M}_{\mathrm{x}}\left(\mathrm{SO}_{4}\right)_{\mathrm{y}}$ formed on the surface of the toxic catalyst. Since the thermal decomposition temperature of $\left(\mathrm{NH}_{4}\right)_{2} \mathrm{SO}_{4}$ and $\mathrm{NH}_{4} \mathrm{HSO}_{4}$ compounds generated on the surface of the catalyst is $200-400^{\circ} \mathrm{C}$ [68], thermal regeneration can decompose the ammonium sulfate salt deposited on the surface of the catalyst to restore the catalytic active site.

$\mathrm{Xu}$ et al. [69] heated the deactivated catalyst to $400^{\circ} \mathrm{C}$ in a fixed-bed

Table 2. Summary of Regeneration of Sulfur Poisoning Catalyst

\begin{tabular}{|c|c|c|c|c|}
\hline Catalyst & Regeneration method & Regeneration conditions & Performance & Ref. \\
\hline 1\%VWTi-r & Thermal regeneration & $400^{\circ} \mathrm{C}, 30 \mathrm{~min}$, in $\mathrm{N}_{2}$ & $85 \%$ & {$[69]$} \\
\hline $\mathrm{Ce}_{0.75} \mathrm{Zr}_{0.25} \mathrm{O}_{2}-\mathrm{PO}_{4}^{3-}$ & Thermal regeneration & $650^{\circ} \mathrm{C}$, under air & over $80 \%$ & {$[70]$} \\
\hline $\mathrm{FeW} / \mathrm{Ti}$ & Thermal regeneration & $400^{\circ} \mathrm{C}, 30 \mathrm{~min}$ & over $90 \%$ & {$[71]$} \\
\hline In/H-BEA & Thermal reduction regeneration & $400^{\circ} \mathrm{C}, 60 \mathrm{~min}$, in $5 \mathrm{vol} . \% \mathrm{H}_{2} / 95$ vol.\%Ar & over $90 \%$ & {$[72]$} \\
\hline $2 \% \mathrm{Ag} /-\mathrm{Al}_{2} \mathrm{O}_{3}$ & Thermal reduction regeneration & $670^{\circ} \mathrm{C}, 40 \mathrm{~min}$, in $\mathrm{H}_{2}$ & over $90 \%$ & {$[73]$} \\
\hline $\mathrm{MnFe} / \mathrm{TiO}_{2}$ & Thermal regeneration & $350^{\circ} \mathrm{C}, 3 \mathrm{~h}$, under air & $35 \%$ & {$[77]$} \\
\hline $\mathrm{MnFe} / \mathrm{TiO}_{2}$ & Water washing regeneration & $1.2 \mathrm{~g} / 50 \mathrm{~mL}$ DI water, $30 \mathrm{~s}$ & $88 \%$ & {$[77]$} \\
\hline
\end{tabular}


quartz reactor and kept it for 30 minutes. The deposited $\mathrm{NH}_{4} \mathrm{HSO}_{4}$ species were decomposed on the surface of the catalyst, and the catalytic ability of the catalyst was recovered. Si et al. [70] regenerated the $\mathrm{Ce}_{0.75} \mathrm{Zr}_{0.25} \mathrm{O}_{2}-\mathrm{PO}_{4}^{3-}$ catalyst in $650^{\circ} \mathrm{C}$ air for $3 \mathrm{~h}$, which could completely regenerate the sulfur aged catalyst. Yu et al. [67] heated the sulfurized $\mathrm{ZnTi}_{10} \mathrm{O}_{\mathrm{x}}-\mathrm{Cu}-\mathrm{SSZ}-13$ and $\mathrm{Cu}-\mathrm{SSZ}-13$ catalysts at $650^{\circ} \mathrm{C}$ for $3 \mathrm{~h}$ in an air atmosphere to regenerate them. Wang et al. [71] found that compared with other catalysts (FeW/Ti, MnW/Ti and $\mathrm{CuW} / \mathrm{Ti}$ ), VW/Ti possessed good regeneration performance and catalytic activity. After thermal regeneration at $400^{\circ} \mathrm{C}$ for 30 minutes, the catalytic activity returned to its original level.

\subsection{Thermal Reduction and Regeneration Method}

Thermal reduction and regeneration method are to mix the inert gas with reducing gas (ammonia gas, hydrogen gas, etc.). Under high temperature, the reducing gas can reduce the ammonium sulfide compound covering the catalyst surface to $\mathrm{SO}_{2}$ and/or $\mathrm{H}_{2} \mathrm{~S}$ to achieve desulfurization and regeneration of the catalyst.

The catalyst showed similar activity with fresh catalyst when the In/H-BEA-S catalyst sulfated for $45 \mathrm{~h}$ at $450^{\circ} \mathrm{C}$ in the $\mathrm{CH}_{4}$-SCR reaction was reduced in $5 \mathrm{vol} \% \mathrm{H}_{2} / \mathrm{Ar}$ for $1 \mathrm{~h}$ [72]. The regeneration mechanisms as shown in Fig. 5. Doronkin et al. [73] heated the $2 \% \mathrm{Ag} /-\mathrm{Al}_{2} \mathrm{O}_{3}$ catalyst used for $\mathrm{H}_{2}$ assisted $\mathrm{NH}_{3}$-SCR in the SCR feed gas at $650-700^{\circ} \mathrm{C}$ and kept for $10-20$ min, and surprisingly detected that the catalyst had exceptional regeneration ability. Chang et al. [74] put forward that the sulfated $\left(\mathrm{Ce}_{3} \mathrm{~W}_{2}\right)_{0.9} \mathrm{Ge}_{0.1} \mathrm{O}_{\mathrm{x}}$ catalysts could be easily regenerated via heating at $300^{\circ} \mathrm{C}$ in $\mathrm{H}_{2}$ atmosphere and the regenerated catalyst showed better activity.



Deactivation



Fig. 5. The mechanisms of regenerated $\mathrm{In} / \mathrm{H}-\mathrm{BEA}$ catalysts [72].

\subsection{Washing Regeneration Method}

Water washing treatment is one of the auxiliary regeneration methods commonly used in industrial catalysts. It can dissolve the soluble sulfate or nitrate generated on the surface of the sulfur poisoning catalyst and the derivative substances produced by $\mathrm{SO}_{2}$ adsorption, so that the active center covered on the catalyst surface can be exposed again. The combination of agitation, ultrasound and other means can enhance the washing effect.

Zhao et al. [75] continuously stirred the deactivated sample in an aqueous solution for $2 \mathrm{~h}$, and then dried it at $105^{\circ} \mathrm{C}$. The results showed that washing regeneration can remove the sulfate species on the catalyst surface, exposing more active sites. After washing and regeneration, the Brønsted acid sites in the catalyst are restored to almost the same level as the fresh catalyst. Hu et al. [76] soaked the sulfur poisoning catalyst in deionized water for 30min, and continuously oscillated it with ultrasonic waves, and then filtered and dried the washed sample. After regeneration, the catalyst activity returned to the initial level. Lee et al. [77] reported that water washing was capable to remove both ammonium salts and metal sulfates on the $\mathrm{MnFe} / \mathrm{TiO}_{2}$ catalysts, and the $\mathrm{NO}_{\mathrm{x}}$ conversion could be recovered to $88 \%$ (compared to $99 \%$ for the fresh catalyst).

Comparing the above regeneration methods, it can be found that the washing regeneration method is simple to operate, low energy consumption, and the regeneration effect is obvious.

\section{Application of Quantum Chemistry in the Field of Sulfur Resistance Research}

With the progress of quantum chemistry technology and the significant improvement of computer computing power, the first-principle calculation based on density functional theory (DFT) has been applied in the field of SCR, which can provide useful help to clarify the mechanism of catalyst sulfur poisoning.

Han et al. [78] used DFT theory to study the $\mathrm{SO}_{2}$ adsorption energy of $\mathrm{m}-\mathrm{TiO}_{2} @ \mathrm{Fe}_{2} \mathrm{O}_{3}$ complex on $\mathrm{TiO}_{2}$-shell and $\mathrm{Fe}_{2} \mathrm{O}_{3}$-nucleus to explain the reason why the composite inhibited sulfate deposition. It was found that the adsorption energy of $\mathrm{SO}_{2}$ on the surface of $\mathrm{TiO}_{2}(101)$, $\left(\mathrm{Fe}_{2} \mathrm{O}_{3}\right)_{2} / \mathrm{TiO}_{2}$ (101) was smaller $(0.21 \mathrm{eV}$ and $0.86 \mathrm{eV}$, respectively), thus it was easy to be replaced by $\mathrm{NO}$ $(1.65 \mathrm{eV})$ and $\mathrm{NH}_{3}(1.90 \mathrm{eV})$ with higher adsorption energy. Fan et al. [22] found that for Ce doped $\mathrm{Mn}$ based catalyst, the $\mathrm{SO}_{2}$ adsorption capacity at Ce site was greater than $\mathrm{Mn}$ site, which prevented the acidification of manganese active site to a certain extent.

Yang et al. [79] used the generalized gradient approximation method (GGA) for periodic density functional theory calculations. The adsorption behavior and sulfation process of copper species $\left(\mathrm{Cu}^{+}, \mathrm{Cu}^{2+}, \mathrm{Cu}^{+} / \mathrm{H}^{+},\left[\mathrm{Cu}{ }^{\mathrm{II}} \mathrm{OH}\right]^{+}\right)$in Cu-SAPO-34 catalyst to $\mathrm{SO}_{2}$ were studied by calculating adsorption energy, energy barrier, charge density, etc. It was found that the electronic and structural properties of copper in the catalyst had great influence on $\mathrm{SO}_{2}$ adsorption, as well as copper with low oxidation state was the main site for $\mathrm{SO}_{2}$ adsorption. $\mathrm{Cu}^{2+}$ is not conducive to $\mathrm{SO}_{2}$ adsorption, but $\mathrm{SO}_{2}$ tends to be adsorbed on $\mathrm{Cu}^{+}$and $\mathrm{Cu}^{+} / \mathrm{H}^{+}$. The authors believed copper species with high oxidation state have difficulty in providing electrons to $\mathrm{SO}_{2} . \mathrm{SO}_{2}$ forms copper sulfate at the $\mathrm{Cu}^{+} / \mathrm{H}^{+}$site, which seriously affects the redox cycle of the SCR reaction $\left(\mathrm{Cu}^{+} \rightarrow \mathrm{Cu}^{2+}\right)$. As a result, the concentration of $\mathrm{Cu}^{2+}$ decreases, which significantly hinders the SCR reaction rate. Hammershøi et al. [80] also confirmed this similar conclusion. 

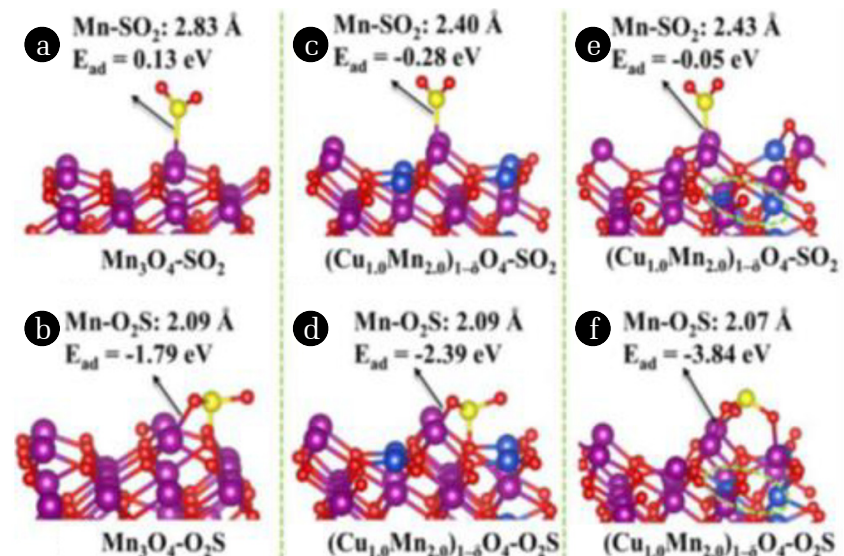

Fig. 6. Model structures of $\mathrm{SO}_{2}$ adsorbed on $\mathrm{Mn}_{3} \mathrm{O}_{4}$ (a), and $\mathrm{Cu}_{1.0} \mathrm{Mn}_{2.01-\delta} \mathrm{O}_{4}$ (c), (e) as "- $\mathrm{Mn}-\mathrm{SO}_{2}$ ". Model structures of $\mathrm{SO}_{2}$ adsorbed on $\mathrm{Mn}_{3} \mathrm{O}_{4}(\mathrm{~b})$, and $\mathrm{Cu}_{1.0} \mathrm{Mn}_{2.01-\delta} \mathrm{O}_{4}(\mathrm{~d})$, (f) as " $-\mathrm{Mn}-\mathrm{O}-\mathrm{S}-\mathrm{O}-\mathrm{Mn}$ $-"$ [30].

Xiong et al. [60] determined the adsorption energy and corresponding bond length of $\mathrm{Mn}_{3} \mathrm{O}_{4}$ and $\mathrm{SO}_{2}$ on the $\left(\mathrm{Cu}_{1.0} \mathrm{Mn}_{2.01-\delta} \mathrm{O}_{4}\right)$ catalyst by DFT calculation (as shown in Fig. 6). It was found that $\mathrm{SO}_{2}$ could hardly be adsorbed on the two model catalysts in the form of "-Mn- $\mathrm{SO}_{2}$ ", and their adsorption energy is close to 0 . However, it is easy to adsorb in the form of "-Mn-O-S-O-Mn-", one $\mathrm{O}$ in $\mathrm{SO}_{2}$ combines with $\mathrm{Mn}$, as well as one $\mathrm{S}$ in $\mathrm{SO}_{2}$ is combined with the terminal $\mathrm{O}$ in "O-Mn-", while the "-Mn-O-S-O-Cu" structure is very unstable. The "O-Cu" bond in this structure is easily broken, and the residual $\mathrm{O}$ combines with another $\mathrm{Mn}$ to form "-Mn-O-S-O-Mn-". This shows that $\mathrm{SO}_{2}$ cannot be adsorbed on the copper ions in $\left(\mathrm{Cu}_{1.0} \mathrm{Mn}_{2.01-\delta} \mathrm{O}_{4}\right)$ spinel. $\mathrm{SO}_{2}$ is easier to use "-Mn-O-S-O-Mn-" form adsorption, doping $\mathrm{Cu}$ in $\mathrm{Mn}_{3} \mathrm{O}_{4}$ reduces the content of adjacent $\mathrm{Mn}$, thus preventing the formation of $\mathrm{MnSO}_{4}$ on the spinel. Wei et al. [49] found that Cr can convert sulfur to Brønsted acid sites by comparing the dissociation energy barrier of $\mathrm{NH}_{3}$ on doped catalysts of different elements and analyzing the projected density of state (PDOS) of $\mathrm{SO}_{2}$ adsorption, and this element can be used as a potential dopant for modified manganese catalysts.

\section{Conclusions and Outlook}

Selective catalytic reduction technology is an effective method to eliminate $\mathrm{NO}_{\mathrm{x}}$ in flue gas, but the residual $\mathrm{SO}_{2}$ in flue gas will inevitably affect the activity of the catalyst, reduce the catalytic efficiency, and shorten the catalytic life. Therefore, exploring the effect of sulfur on the activity of the catalytic system and the mechanism of sulfur poisoning of the catalyst is crucial to the development of a deNO ${ }_{x}$ catalyst that combines high efficiency and long life. At present, the potential causes of sulfur poisoning mechanism of catalysts can be classified as follows: competitive adsorption between $\mathrm{SO}_{2}$ and $\mathrm{NO}_{\mathrm{x}}$; sulfation of active center atoms, formation and deposition of ammonium sulfate on the catalyst surface, resulting in blockage of catalyst channels. From the point of existing achievements, reducing/ avoiding the sulfation of catalyst active sites is an effective strategy to improve the sulfur resistance of the catalyst, which can be achieved by adding components, improving the support, and regulating the structure and morphology of the catalyst.

Nowadays, tremendous efforts have been devoted to focuses on the denitrification efficiency and deactivation mechanism of catalyst in the presence of single sulfur toxicity factor, there are few studies on the deactivation mechanism of the catalyst and the regeneration of the deactivated catalyst in the presence of multiple toxic factors, so future research on the SCR catalyst can be considered from the following aspects:

(1) Deactivation of catalysts has always been a key problem in selective catalytic reduction of nitrogen oxides. The deactivation of most denitration catalysts is not affected by a single factor, and the deactivation reasons are complex. The fly ash particles in the flue gas, alkali metals $(\mathrm{K}, \mathrm{Na})$, alkaline earth metals (Ca, Mg), heavy metals ( $\mathrm{Pb}, \mathrm{As}$ ), etc. all have a toxic effect on the catalyst. The deactivation mechanism of catalyst is worthy of further study. It is also necessary to develop catalyst with excellent resistance to various poisons according to the deactivation mechanism of different toxic factors, which provides beneficial attempt and exploration for industrial application.

(2) The deactivation of the catalyst is not caused by a single factor, and the effect of a single regeneration method is limited. Therefore, it is necessary to explore the combined regeneration method to achieve the ideal regeneration effect.

(3) Theoretical calculation is an important research method in the field of environmental catalysis, which helps to clarify the reaction mechanism that is difficult to obtain only through experimental research. At present, the research on the application of quantum chemistry in SCR field is very limited. The theoretical calculation and experiment can be further combined to develop efficient, stable, long service life and environment-friendly deNO $\mathrm{N}_{\mathrm{x}}$ catalyst materials.

\section{Acknowledgments}

We acknowledge the financial support of the National Natural Science Foundation of China (Nos. 21866022, 21567018).

\section{Author Contributions}

L.Z. (Associate Professor) wrote and revised the manuscript. Y.Z (Master student) wrote and revised the manuscript. M.D.K (Master student) revised the manuscript.

\section{References}

1. Zeng YY, Gao YC, Qiao X, Seyler BC, Tang Y. Air pollution reduction in China: Recent success but great challenge for the future. Sci. Total Environ. 2019;663:329-337.

2. Liu MH, Liu T, Xiao CL. Research progress of low temperature selective catalytic reduction (SCR) catalysts for denitrification. 
World Nonferrous Metal 2018;21:170-175.

3. Wang XW, Li LL, Sun JF, Wan HQ, Tang CJ, Gao F. Analysis of $\mathrm{NO}_{\mathrm{x}}$ emission and control in China and research progress in denitration catalysts. Industrial Catalysis 2019;27:1-23.

4. Ning RL, Liu XI, Zhu TY. Research progress of low-temperature SCR denitration catalysts. Chin. J. Mech. Eng. EN. 2019;19: 223-234.

5. Kang L, Han LP, He JB, Li HR, Yan TT, Chen GR. Improved $\mathrm{NO}_{\mathrm{x}}$ reduction in the presence of $\mathrm{SO}_{2}$ by using $\mathrm{Fe}_{2} \mathrm{O}_{3}$-promoted halloysite-supported $\mathrm{CeO}_{2}-\mathrm{WO}_{3}$ catalysts. Environ. Sci. Technol. 2019;53:938-945.

6. Zha KW, Feng C, Han LP, Li HR, Yan TT, Kuboon SC. Promotional effects of $\mathrm{Fe}$ on manganese oxide octahedral molecular sieves for alkali-resistant catalytic reduction of $\mathrm{NO}_{\mathrm{x}}$ : XAFS and in situ DRIFTs study. Chem. Eng. J. 2020;381:122764.

7. Kang L, Han LP, Wang PL, et al. $\mathrm{SO}_{2}$-Tolerant $\mathrm{NO}_{\mathrm{x}}$ reduction by marvelously suppressing $\mathrm{SO}_{2}$ adsorption over $\mathrm{Fe}_{\delta} \mathrm{Ce}_{1-\delta} \mathrm{VO}_{4}$ catalysts. Environ. Sci. Technol. 2020;54:14066-14075.

8. Zeng YQ, Song W, Wang YN, Zhang SL, Wang TX, Zhang Q. Novel Fe-doped $\mathrm{CePO}_{4}$ catalyst for selective catalytic reduction of $\mathrm{NO}$ with $\mathrm{NH}_{3}$ : The role of $\mathrm{Fe}^{3+}$ ions. J. Hazard. Mater. 2020;383:121212.

9. Jia XX, Liu H, Zhang Y, et al. Understanding the high performance of an iron-antimony binary metal oxide catalyst in selective catalytic reduction of nitric oxide with ammonia and its tolerance of water/sulfur dioxide. J. Colloid Interface Sci. 2021;581:427-441.

10. Wang H, Qu ZP, Dong SC, Xie HB, Tang C. Superior Performance of $\mathrm{Fe}_{1-\mathrm{x}} \mathrm{W}_{\mathrm{x}} \mathrm{O}_{\delta}$ for the selective catalytic reduction of $\mathrm{NO}_{\mathrm{x}}$ with $\mathrm{NH}_{3}$ : Interaction between Fe and W. Environ. Sci. Technol. 2016;50:13511-13519.

11. Li YL, Liu WM, Yan R, Liang J, Tao M, Mi YY. Hierarchical three-dimensionally ordered macro porous Fe-V binary metal oxide catalyst for low temperature selective catalytic reduction of $\mathrm{NO}_{\mathrm{x}}$ from marine diesel engine exhaust. Appl. Catal., B 2020;268:118455.

12. Zhu N, Shan WP, Lian ZH, Zhang Y, Liu K, He H. A superior Fe-V-Ti catalyst with high activity and $\mathrm{SO}_{2}$ resistance for the selective catalytic reduction of $\mathrm{NO}_{\mathrm{x}}$ with $\mathrm{NH}_{3}$. J. Hazard. Mater. 2020;382:120970.

13. Dong SL, Su YX, Liu X, Li QC, Yuan MH, Zhou H. Experimental study on selective catalytic reduction of $\mathrm{NO}$ by $\mathrm{C}_{3} \mathrm{H}_{6}$ over Fe/Ti-PILC catalysts. J. Fuel Chem. Technol. 2018;46:1231-1239.

14. Qian WY, Su YX, Yang X, Yuan MH, Deng EY, Zhao BT. Experimental study on selective catalytic reduction of NO with propene over iron based catalysts supported on aluminum pillared clays. J. Fuel Chem. Technol. 2017;45:1499-1507.

15. Wang LY, Cheng XX, Wang ZQ, Sun RF, Zhao GJ, Feng T. Reaction of $\mathrm{NO}+\mathrm{CO}$ over Ce-modified $\mathrm{Cu}-\mathrm{FeO}_{\mathrm{x}}$ catalysts at low temperature. Energy Fuels 2019;33:11688-11704.

16. Fang NJ, Guo JX, Shu S, Luo HD, Li JJ, Chu YH. Effect of calcination temperature on low-temperature $\mathrm{NH}_{3}$-SCR activity and the resistance of $\mathrm{SO}_{2}$ with or without $\mathrm{H}_{2} \mathrm{O}$ over Fe-Mn- $\mathrm{Fr}$ catalyst. J. Taiwan Inst. Chem. Eng. 2018;93:277-288.

17. Wang JY, Nie ZG, An ZW, et al. Improvement of $\mathrm{SO}_{2}$ resistance of low-temperature Mn-Based denitration catalysts by $\mathrm{Fe}$ doping. ACS Omega 2019;4:3755-3760.
18. Xie AJ, Tao YY, Jin X, et al. A $\gamma$-Fe2O3-modified nanoflower- $\mathrm{MnO}_{2}$ /attapulgite catalyst for low temperature SCR of $\mathrm{NO}_{x}$ with $\mathrm{NH}_{3}$. New J. Chem. 2019;43;2490-2500.

19. Chen JJ, Zhao WT, Wu Q, Mi JX, Wang XY, Ma L. Effects of anaerobic $\mathrm{SO}_{2}$ treatment on nano- $\mathrm{CeO}_{2}$ of different morphologies for selective catalytic reduction of $\mathrm{NO}_{\mathrm{x}}$ with $\mathrm{NH}_{3}$. Chem. Eng. J. 2020;382:122910.

20. Chen JY, Fu P, Lv DF, et al. Unusual positive effect of $\mathrm{SO}_{2}$ on Mn-Ce mixed-oxide catalyst for the SCR reaction of $\mathrm{NO}_{x}$ with $\mathrm{NH}_{3}$. Chem. Eng. J. 2021;407:127071.

21. Wang XB, Duan RB, Liu W, Wang DW, Wang BR, Xu YR. The insight into the role of $\mathrm{CeO}_{2}$ in improving low-temperature catalytic performance and $\mathrm{SO}_{2}$ tolerance of $\mathrm{MnCoCeO}_{\mathrm{x}}$ microflowers for the $\mathrm{NH}_{3}$-SCR of $\mathrm{NO}_{x}$. Appl. Surf. Sci. 2020;510: 145517.

22. Fan YM, Ling W, Huang BC, Dong LF, Yu CL, Xi HX. The synergistic effects of cerium presence in the framework and the surface resistance to $\mathrm{SO}_{2}$ and $\mathrm{H}_{2} \mathrm{O}$ in $\mathrm{NH}_{3}$-SCR. J. Ind. Eng Chem. 2017;56:108-119.

23. Zhang WJ, Liu GF, Jiang J, et al. Temperature sensitivity of the selective catalytic reduction (SCR) performance of $\mathrm{Ce}-\mathrm{TiO}_{2}$ in the presence of $\mathrm{SO}_{2}$. Chemosphere 2020;243:125419.

24. Kwon DW, Nam KB, Hong SC. The role of ceria on the activity and $\mathrm{SO}_{2}$ resistance of catalysts for the selective catalytic reduction of $\mathrm{NO}_{x}$ by $\mathrm{NH}_{3}$. Appl. Catal., B 2015;166-167:37-44.

25. Shu Y, Aikebaier T, Quan X, Chen S, Yu HT. Selective catalytic reaction of $\mathrm{NO}_{\mathrm{x}}$ with $\mathrm{NH}_{3}$ over $\mathrm{Ce}-\mathrm{Fe} / \mathrm{TiO}_{2}$-loaded wire-mesh honeycomb: Resistance to $\mathrm{SO}_{2}$ poisoning. Appl. Catal., B 2014;150-151:630-635.

26. Ma SB, Tan HS, Li YS, et al. Excellent low-temperature $\mathrm{NH}_{3}-\mathrm{SCR}$ NO removal performance and enhanced $\mathrm{H}_{2} \mathrm{O}$ resistance by Ce addition over the $\mathrm{Cu}_{0.02} \mathrm{Fe}_{0.2} \mathrm{Ce}_{\mathrm{y}} \mathrm{Ti}_{1-\mathrm{y}} \mathrm{O}_{\mathrm{x}}(\mathrm{y}=0.1,0.2,0.3)$ catalysts Chemosphere 2020;243:125309.

27. Yao XJ, Kang KK, Cao J, et al. Enhancing the denitration performance and anti-K poisoning ability of $\mathrm{CeO}_{2}-\mathrm{TiO}_{2} / \mathrm{P} 25$ catalyst by $\mathrm{H}_{2} \mathrm{SO}_{4}$ pretreatment: Structure-activity relationship and mechanism study. Appl. Catal., B 2020;269:118808.

28. Liu CX, Bi YL, Li JH. Activity enhancement of sulphated $\mathrm{Fe}_{2} \mathrm{O}_{3}$ supported on $\mathrm{TiO}_{2}-\mathrm{ZrO}_{2}$ for the selective catalytic reduction of $\mathrm{NO}$ by $\mathrm{NH}_{3}$. Appl. Surf. Sci. 2020;528:146695.

29. Li G, Mao DS, Chao MX, Li GH, Yu J, Guo XM. Low-temperature $\mathrm{NH}_{3}$-SCR of $\mathrm{NO}_{\mathrm{x}}$ over $\mathrm{MnCeO}_{\mathrm{x}} / \mathrm{TiO}_{2}$ catalyst: Enhanced activity and $\mathrm{SO}_{2}$ tolerance by modifying $\mathrm{TiO}_{2}$ with $\mathrm{Al}_{2} \mathrm{O}_{3}$. J. Rare Earths.

30. Wang XQ, Liu Y, Wu ZB. Highly active $\mathrm{NbOPO}_{4}$ supported $\mathrm{Cu}$-Ce catalyst for $\mathrm{NH}_{3}$-SCR reaction with superior sulfur resistance. Chem. Eng. J. 2020;382:122941.

31. Wu X, Meng H, Du YL, Liu JN, Hou BH, Xie XM. Fabrication of highly dispersed Cu-based Oxides as desirable $\mathrm{NH}_{3}$-SCR catalysts via employing CNTs To decorate the CuAl-layered double hydroxides. ACS Appl. Mater. Interfaces 2019;11:3291732927.

32. Han J, Meeprasert J, Maitarad P, Nammuangruk S, Shi LY, Zhang DS. Investigation of the facet-dependent catalytic performance of $\mathrm{Fe}_{2} \mathrm{O}_{3} / \mathrm{CeO}_{2}$ for the selective catalytic reduction of NO with $\mathrm{NH}_{3}$. J. Phys. Chem. C 2016;120:1523-1533.

33. Gao FY, TangXL, Sani Z, et al. Spinel-structured Mn-Ni nanosheets for $\mathrm{NH}_{3}-\mathrm{SCR}$ of $\mathrm{NO}$ with good $\mathrm{H}_{2} \mathrm{O}$ and $\mathrm{SO}_{2}$ resistance 
at low temperature. Catal. Sci. Technol. 2020;22(10):7486-7501.

34. Zhang ZP, Li RM, Wang M, et al. Two steps synthesis of $\mathrm{CeTiO}_{x}$ oxides nanotube catalyst: Enhanced activity,resistance of $\mathrm{SO}_{2}$ and $\mathrm{H}_{2} \mathrm{O}$ for low temperature $\mathrm{NH}_{3}$-SCR of $\mathrm{NO}_{x}$. Appl. Catal., B 2021;282:119542.

35. Huang ZW, Li H, Gao JY, et al. Alkali- and sulfur-resistant tungsten-based catalysts for $\mathrm{NO}_{\mathrm{x}}$ emissions control. Environ. Sci. Technol. 2015;49:14460-14465.

36. Guo K, Fan GF, Gu D, et al. Pore size expansion accelerates ammonium bisulfate decomposition for improved sulfur resistance in low-temperature $\mathrm{NH}_{3}$-SCR. ACS Appl. Mater. Interfaces 2019;11:4900-4907.

37. Sheng ZY, Ma DR, Yu DQ. Synthesis of novel MnO $@ \mathrm{TiO}_{2}$ core-shell nanorod catalyst for low-temperature $\mathrm{NH}_{3}$-selective catalytic reduction of $\mathrm{NO}_{x}$ with enhanced $\mathrm{SO}_{2}$ tolerance. Chin. J. Catal. 2018;39:821-830.

38. Gan LN, Li KZ, Yang WN, Chen JJ. Core-shell-like structured $\alpha-\mathrm{MnO}_{2} @ \mathrm{CeO}_{2}$ catalyst for selective catalytic reduction of NO: Promoted activity and $\mathrm{SO}_{2}$ tolerance. Chem. Eng. J. 2020;391: 123473.

39. Ma DR, Yang L, Huang BJ, et al. $\mathrm{MnO}_{\mathrm{x}}-\mathrm{CeO}_{2} @ \mathrm{TiO}_{2}$ core-shell composites for low temperature SCR of $\mathrm{NO}_{\mathrm{x}}$. New J. Chem. 2019;43:15161-15168.

40. Zhang HW, Zhang MZ, Hao LF, et al. Enhanced $\mathrm{SO}_{2}$ tolerance of $\mathrm{FeCeO}_{x} / \mathrm{CNT}$ catalyst for $\mathrm{NO}$ and $\mathrm{Hg}^{0}$ removal by coating shell $\mathrm{SiO}_{2}$. Fuel Process. Technol. 2020;201:106342.

41. Yu CL, Hou D, Huang BC, Lu MJ, Peng RS, Zhong ZY. A $\mathrm{MnO}_{\mathrm{x}} @ \mathrm{Eu}-\mathrm{CeO}_{\mathrm{x}}$ nanorod catalyst with multiple protective effects: Strong $\mathrm{SO}_{2}$-tolerance for low temperature $\mathrm{DeNO}_{\mathrm{x}}$ processes. J. Hazard. Mater. 2020;399:123011.

42. Cai SX, Hu H, Li HR, Shi LY, Zhang DS. Design of multi-shell $\mathrm{Fe}_{2} \mathrm{O}_{3} @ \mathrm{MnO}_{\mathrm{x}} @ \mathrm{CNT}$ for the selective catalytic reduction of $\mathrm{NO}$ with $\mathrm{NH}_{3}$ : improvement of catalytic activity and $\mathrm{SO}_{2}$ tolerance. Nanoscale 2016;8:3588-3598.

43. Ma ZX, Sheng LP, Wang XW, et al. Oxide catalysts with ultrastrong resistance to $\mathrm{SO}_{2}$ deactivation for removing nitric oxide at low temperature. Adv. Mater. 2019;31:1903719.

44. Liang QM, Li J, He H, Yue Tao, Tong Li. Effects of $\mathrm{SO}_{2}$ and $\mathrm{H}_{2} \mathrm{O}$ on low-temperature $\mathrm{NO}$ conversion over $\mathrm{F}-\mathrm{V}_{2} \mathrm{O}_{5}-\mathrm{WO}_{3} / \mathrm{TiO}_{2}$ catalysts. J. Environ. Sci. 2020;90:253-261.

45. Kang TH, Youn S, Kim DH. Improved catalytic performance and resistance to $\mathrm{SO}_{2}$ over $\mathrm{V}_{2} \mathrm{O}_{5}-\mathrm{WO}_{3} / \mathrm{TiO}_{2}$ catalyst physically mixed with $\mathrm{Fe}_{2} \mathrm{O}_{3}$ for low-temperature $\mathrm{NH}_{3}$-SCR. Catal. Today. 2020. (In Press, Corrected Proof)

46. Mu JC, Li XY, Wang XY, et al. New insight into the effects of $\mathrm{NH}_{3}$ on $\mathrm{SO}_{2}$ poisoning for in situ removal of metal sulfates in low-temperature $\mathrm{NH}_{3}$-SCR over an $\mathrm{Fe}-\mathrm{V}$ catalyst. J. Phys. Chem. C 2020;124:21396-21406.

47. Li CX, Shen MQ, Wang JQ, Wang J, Zhai YP. New insights into the role of $\mathrm{WO}_{3}$ in improved activity and ammonium bisulfate resistance for $\mathrm{NO}$ reduction with $\mathrm{NH}_{3}$ over $\mathrm{V}-\mathrm{W} / \mathrm{Ce} / \mathrm{Ti}$ catalyst. Ind. Eng. Chem. Res. 2018;57:8424-8435.

48. Gao FY, Tang XL, Yi HH, Li JY, Zhao SZ, Wang JG. Promotional mechanisms of activity and $\mathrm{SO}_{2}$ tolerance of $\mathrm{Co}^{-}$or Ni-doped $\mathrm{MnO}_{\mathrm{x}}-\mathrm{CeO}_{2}$ catalysts for SCR of $\mathrm{NO}_{\mathrm{x}}$ with $\mathrm{NH}_{3}$ at low temperature. Chem. Eng. J. 2017;317:20-31.

49. Wei L, Cui SP, Guo HX. Study the low-temperature SCR property of M-doped ( $\mathrm{M}=\mathrm{Ni}, \mathrm{Cr}$, Co, Se, Sn) $\mathrm{MnO}_{2}(100)$ through density functional theory (DFT): Improvement of sulfur poisoning resistance. Mol. Catal 2018;459:31-37.

50. Jiang HX, Wang J, Zhou JL, Chen YF, Zhang MH. Effect of promoters on the catalytic performance and $\mathrm{SO}_{2} / \mathrm{H}_{2} \mathrm{O}$ resistance of $\alpha-\mathrm{MnO}_{2}$ catalysts for low temperature $\mathrm{NH}_{3}$-SCR. Ind. Eng. Chem. Res. 2019;58:1760-1768.

51. Sun P, Huang SX, Guo RT, Li MY, Liu, SM. The enhanced SCR performance and $\mathrm{SO}_{2}$ resistance of $\mathrm{Mn} / \mathrm{TiO}_{2}$ catalyst by the modification with $\mathrm{Nb}$ : A mechanistic study. Appl. Surf. Sci. 2018;447:479-488.

52. Liu J, Guo RT, Li MY, Sun P, Liu SM. Enhancement of the $\mathrm{SO}_{2}$ resistance of $\mathrm{Mn} / \mathrm{TiO}_{2}$ SCR catalyst by Eu modification: A mechanism study. Fuel 2018;223:385-393.

53. Liu L, Xu K, Su S. Efficient Sm modified $\mathrm{Mn} / \mathrm{TiO}_{2}$ catalysts for selective catalytic reduction of $\mathrm{NO}$ with $\mathrm{NH}_{3}$ at low temperature. Appl. Catal., A 2020;592:117413.

54. Wang B, Wang MX, Han LN, et al. Improved activity and $\mathrm{SO}_{2}$ resistance by $\mathrm{Sm}$-modulated redox of $\mathrm{MnCeSmTiO}_{\mathrm{x}}$ mesoporous amorphous oxides for low-temperature $\mathrm{NH}_{3}$-SCR of NO. ACS Catal. 2020;10:9034-9045.

55. Zhang XL, Lv SS, Zhang XC, Xiao KS, Wu XP. Improvement of the activity and $\mathrm{SO}_{2}$ tolerance of Sb-modified $\mathrm{Mn} / \mathrm{PG}$ catalysts for $\mathrm{NH}_{3}$-SCR at a low temperature. J. Environ. Sci. 2020;101:1-15.

56. Liu Z, Wang MM, Liu SJ, Chen Z, Yang LZ. Design of assembled composite of $\mathrm{Mn}_{3} \mathrm{O}_{4} @$ Graphitic carbon porous nano-dandelions: A catalyst for low-temperature selective catalytic reduction of $\mathrm{NO}_{\mathrm{x}}$ with remarkable $\mathrm{SO}_{2}$ resistance. Appl. Catal., B 2020;269:118731.

57. Fan ZY, Shi JW, Niu CH, Wang BR, He C, Cheng YH. The insight into the role of $\mathrm{Al}_{2} \mathrm{O}_{3}$ in promoting the $\mathrm{SO}_{2}$ tolerance of $\mathrm{MnO}_{\mathrm{x}}$ for low-temperature selective catalytic reduction of $\mathrm{NO}_{x}$ with $\mathrm{NH}_{3}$. Chem. Eng. J. 2020;398:125572.

58. Gao FY, Tang XL, Yi HH. Novel Co- or Ni-Mn binary oxide catalysts with hydroxyl groups for $\mathrm{NH}_{3}-\mathrm{SCR}$ of $\mathrm{NO}_{\mathrm{x}}$ at low temperature. Appl. Surf. Sci. 2018;443:103-113.

59. Gao FY, Tang XL, Yi HH, Zhao SZ, Zhu WJ, Shi YR. $\mathrm{Mn}_{2} \mathrm{NiO}_{4}$ spinel catalyst for high-efficiency selective catalytic reduction of nitrogen oxides with good resistance to $\mathrm{H}_{2} \mathrm{O}$ and $\mathrm{SO}_{2}$ at low temperature. J. Environ. Sci. 2020;89:145-155.

60. Xiong SC, Peng Y, Wang D, Huang N, Zhang QF. The role of the $\mathrm{Cu}$ dopant on a $\mathrm{Mn}_{3} \mathrm{O}_{4}$ spinel SCR catalyst: Improvement of low-temperature activity and sulfur resistance J. Chem. Eng. J. 2020;387:124090.

61. Yan QH, Chen SN, Zhang C, Wang Q, Louis B. Synthesis and catalytic performance of $\mathrm{Cu}_{1} \mathrm{Mn}_{0.5} \mathrm{Ti}_{0.5} \mathrm{O}_{\mathrm{x}}$ mixed oxide as low-temperature $\mathrm{NH}_{3}$-SCR catalyst with enhanced $\mathrm{SO}_{2}$ resistance. Appl. Catal., B 2018;238:236-247.

62. Chen SN, Yan QH, Zhang C, Wang Q. A novel highly active and sulfur resistant catalyst from $\mathrm{Mn}-\mathrm{Fe}-\mathrm{Al}$ layered double hydroxide for low temperature $\mathrm{NH}_{3}$-SCR. Catal Today 2019;327:81-89.

63. Zhou X, Yu F, Sun RB, Tian JQ, Wang Q, Dai B. Two-dimensional MnFeCo layered double oxide as catalyst for enhanced selective catalytic reduction of $\mathrm{NO}_{\mathrm{x}}$ with $\mathrm{NH}_{3}$ at low temperature (25-150 ${ }^{\circ}$ ). Appl. Catal., A 2020;592:117432.

64. Peng C, Yan R, Peng HG, et al. One-pot synthesis of layered 
mesoporous ZSM-5 plus Cu ion-exchange: Enhanced $\mathrm{NH}_{3}$-SCR performance on Cu-ZSM-5 with hierarchical pore structures. J. Hazard. Mater. 2020;385:121593.

65. Ma YY, Li ZF, Zhao N, Teng YL. One-pot synthesis of Cu-Ce co-doped SAPO-5/34 hybrid crystal structure catalysts for $\mathrm{NH}_{3}$-SCR reaction with $\mathrm{SO}_{2}$ resistance. J. Rare Earths. 2020. (In press)

66. Wan J, Chen JW, Zhao R, Zhou RX. One-pot synthesis of $\mathrm{Fe} / \mathrm{Cu}-\mathrm{SSZ}-13$ catalyst and its highly efficient performance for the selective catalytic reduction of nitrogen oxide with ammonia. J. Environ. Sci. 2021;100:306-316.

67. Yu R, Zhao ZC, Huang SJ, Zhang WP. Cu-SSZ-13 zeolite-metal oxide hybrid catalysts with enhanced $\mathrm{SO}_{2}$-tolerance in the $\mathrm{NH}_{3}$-SCR of $\mathrm{NO}_{x}$. Appl. Catal., B 2020;269:118825.

68. Zhou J, Wang BD, Ma J, Li G. $\mathrm{SO}_{2}$ and $\mathrm{H}_{2} \mathrm{O}$ poisoning resistance of manganese oxide-based catalysts for low-temperature selective catalytic reduction of $\mathrm{NO}_{x}$. Environ. Chem. 2018;37: 782-791.

69. Xu LW, Wang CZ, Chang HZ, Wu QR, Zhang T, Li JH. New insight into $\mathrm{SO}_{2}$ poisoning and regeneration of $\mathrm{CeO}_{2}-\mathrm{WO}_{3} / \mathrm{TiO}_{2}$ and $\mathrm{V}_{2} \mathrm{O}_{5}-\mathrm{WO}_{3} / \mathrm{TiO}_{2}$ catalysts for low-temperature $\mathrm{NH}_{3}-\mathrm{SCR}$. Environ. Sci. Technol. 2018;52:7064-7071.

70. Si ZC, Weng D, Wu XD, Wu XD. $\mathrm{NH}_{3}$-SCR activity, hydrothermal stability, sulfur resistance and regeneration of $\mathrm{Ce}_{0.75} \mathrm{Zr}_{0.25}$ $\mathrm{O}_{2}-\mathrm{PO}_{4}{ }^{3-}$ catalyst. Catal. Commun. 2012;17:146-149.

71. Wang YZ, Yi W, Yu J, Zeng J, Chang HZ. Novel methods for assessing the $\mathrm{SO}_{2}$ poisoning effect and thermal regeneration possibility of $\mathrm{MO}_{\mathrm{x}}-\mathrm{WO}_{3} / \mathrm{TiO}_{2}(\mathrm{M}=\mathrm{Fe}, \mathrm{Mn}, \mathrm{Cu}$, and V) catalysts for $\mathrm{NH}_{3}$-SCR. Environ. Sci. Technol. 2020;54:12612-12620.

72. Pan H, Jian YF, Yu YK, He C, Shen ZX. Regeneration and sulfur poisoning behavior of $\mathrm{In} / \mathrm{H}-\mathrm{BEA}$ catalyst for $\mathrm{NO}_{\mathrm{x}}$ reduction by $\mathrm{CH}_{4}$. Appl. Surf. Sci. 2017;401:120-126.

73. Doronkin DE, Khan TS, Bligaard T, Fogle S, Bligaard T, Dahl S. Sulfur poisoning and regeneration of the $\mathrm{Ag} / \gamma-\mathrm{Al}_{2} \mathrm{O}_{3}$ catalyst for $\mathrm{H}_{2}$-assisted SCR of $\mathrm{NO}_{\mathrm{x}}$ by ammonia J. Appl. Catal., $B$ 2012;117-118:49-58.

74. Chang $\mathrm{HZ}$, $\mathrm{Li}$ JH, Yuan J, et al. Ge, Mn-doped $\mathrm{CeO}_{2}-\mathrm{WO}_{3}$ catalysts for $\mathrm{NH}_{3}-\mathrm{SCR}$ of $\mathrm{NO}_{\mathrm{x}}$ : Effects of $\mathrm{SO}_{2}$ and $\mathrm{H}_{2}$ regeneration. Catal. Today 2013;201:139-144.

75. Zhao L, Yang SW, Duan J, Liu QF. Improved NO reduction in the presence of $\mathrm{SO}_{2}$ by using $\mathrm{Zr}$-promoted calcined $\mathrm{NiAl}$ hydrotalcite-like compounds and the regeneration of deactivated catalysts. Fuel 2020;263:116668.

76. Hu YF, Xue JM, Wang XM, Sheng CY, Liao WP. Research on characteristics of $\mathrm{SO}_{2}$-poison and regeneration of $\mathrm{Mn}-\mathrm{Ce} / \mathrm{TiO}_{2}$ catalyst for low temperature selective catalytic reduction. Industrial Catalysis 2013;21:27-33.

77. Lee T, Bai H. Metal sulfate poisoning effects over $\mathrm{MnFe} / \mathrm{TiO}_{2}$ for selective catalytic reduction of $\mathrm{NO}$ by $\mathrm{NH}_{3}$ at low temperature. Ind. Eng. Chem. Res. 2018;57:4848-4858.

78. Han LP, Gao M, Hasegawa JY, Li SX. $\mathrm{SO}_{2}$-tolerant selective catalytic reduction of $\mathrm{NO}_{x}$ over Meso-TiO $\mathrm{T}_{2} @ \mathrm{Fe}_{2} \mathrm{O}_{3} @ \mathrm{Al}_{2} \mathrm{O}_{3}$ metal-based monolith catalysts. Environ. Sci. Technol. 2019;53: 6462-6473.

79. Yang GP, Du XS, Ran JY, Wang XM, Chen YR, Zhang L. Understanding $\mathrm{SO}_{2}$ poisoning over different copper species of Cu-SAPO-34 catalyst: A periodic DFT study. J. Phys. Chem. C 2018;122:21468-21477.

80. Hammershøi PS, Vennestrøm PNR, Falsig H, Jensen AD. Importance of the $\mathrm{Cu}$ oxidation state for the $\mathrm{SO}_{2}$-poisoning of a Cu-SAPO-34 catalyst in the $\mathrm{NH}_{3}$-SCR reaction. Appl. Catal., B 2018;236:377-383. 